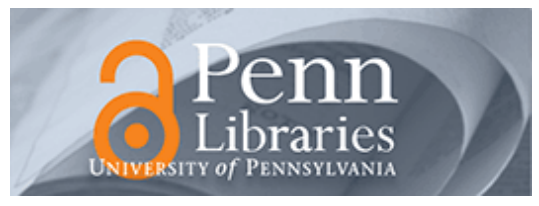

University of Pennsylvania

ScholarlyCommons

Accounting Papers

Wharton Faculty Research

2012

\title{
Corporate Governance and the Information Environment: Evidence From State Antitakeover Laws
}

Christopher S. Armstrong

University of Pennsylvania

Karthik Balakrishnan

University of Pennsylvania

Follow this and additional works at: https://repository.upenn.edu/accounting_papers

Part of the Accounting Commons

\section{Recommended Citation}

Armstrong, C. S., \& Balakrishnan, K. (2012). Corporate Governance and the Information Environment: Evidence From State Antitakeover Laws. Journal of Accounting and Economics, 53 (1-2), 185-204. http://dx.doi.org/10.1016/j.jacceco.2011.06.005

This paper is posted at ScholarlyCommons. https://repository.upenn.edu/accounting_papers/110

For more information, please contact repository@pobox.upenn.edu. 


\title{
Corporate Governance and the Information Environment: Evidence From State Antitakeover Laws
}

\author{
Abstract \\ We examine the relation between corporate governance and firms' information environments. We use the \\ passage of state antitakeover laws in the U.S. as a source of exogenous variation in an important \\ governance mechanism to identify changes in firms' information environments. We find that information \\ asymmetry and private information gathering decreased and that financial statement informativeness \\ increased following the passage of the antitakeover laws. Cross-sectional analyses indicate that the \\ increased level of financial statement informativeness is attributable to firms that are most likely to \\ access equity markets rather than managerial entrenchment, managerial career concerns, or managers' \\ pursuit of the quiet life.

\section{Keywords} \\ antitakeover laws, corporate governance, financial reporting quality, information asymmetry \\ Disciplines \\ Accounting
}




\title{
Corporate Governance and the Information Environment: Evidence from State Antitakeover Laws
}

\author{
Christopher S. Armstrong \\ carms@wharton.upenn.edu \\ Karthik Balakrishnan \\ kbalakri@wharton.upenn.edu \\ The Wharton School \\ University of Pennsylvania \\ 1300 Steinberg-Dietrich Hall \\ Philadelphia, PA 19104-6365 \\ Daniel Cohen \\ dcohen@utdallas.edu \\ University of Texas at Dallas \\ 800 W. Campbell Road SM 41 \\ Richardson, TX 75080
}

June 17, 2011

\begin{abstract}
We examine the relation between corporate governance and firms' information environments. We use the passage of state antitakeover laws in the U.S. as a source of exogenous variation in an important governance mechanism to identify changes in firms' information environments. We find that information asymmetry and private information gathering decreased and that financial statement informativeness increased following the passage of the antitakeover laws. Cross-sectional analyses indicate that the increased level of financial statement informativeness is attributable to firms that are most likely to access equity markets rather than managerial entrenchment, managerial career concerns, or managers' pursuit of the quiet life.
\end{abstract}

Keywords: antitakeover laws; corporate governance; financial reporting quality; information asymmetry

We are grateful to Soren Hvidkjaer for providing data on the Probability of Informed Trade. This paper has benefitted from feedback from Ashiq Ali, Anne Beatty, Donal Byard, John Core, Umit Gurun, Raffi Indjejikian, Ilan Kremer, Edward Li, Stan Markov, Ed Owens, Cathy Schrand, Nemit Shroff, Ross Watts (editor), Joanna Wu, Tzachi Zach, Helen Zhang, and an anonymous referee. We also thank seminar participants at Baruch College, Duke University, Erasmus University, Hebrew University of Jerusalem, University of Michigan, University of Pennsylvania (Wharton), University of Texas - Dallas, Ohio State University, and University of Rochester for useful comments and suggestions. We thank Adrian Rush for editorial assistance. Christopher Armstrong is grateful for financial support from the Dorinda and Mark Winkelman Distinguished Scholar Award. 


\section{Introduction}

Corporate governance is typically defined as the set of mechanisms designed to mitigate agency problems that arise between shareholders and managers because of the separation of ownership and control (Jensen, 1993; Shleifer and Vishny, 1997; Core, Guay, and Larcker, 2003; Armstrong, Guay, and Weber, 2010). Information asymmetry between these parties has been identified as the main source of agency problems, which implies that a firm's information environment is a crucial input that affects the design of its corporate governance mechanisms that are implemented to monitor managers. ${ }^{1}$ Not surprisingly, the relation between firms' corporate governance structures and their information environments has been of interest to policy makers, regulators, and academics.

Although corporate governance and various attributes of firms' information environments are invariably linked, the precise nature of the relation between these two constructs is not entirely understood (e.g., Armstrong et al., 2010; Dechow et al., 2010). Further exacerbating the difficulty in establishing the link between firms’ corporate governance structures and their information environment is the endogenous relation between these two constructs (Armstrong et al., 2010). ${ }^{2}$ Not surprisingly, extant empirical studies provide conflicting evidence on the relation between firms' corporate governance structures and their information environments

\footnotetext{
1 Throughout this paper we characterize and refer to the firm's information environment as the variation in information asymmetry between managers and investors, information asymmetry among investors, informativeness of public financial statements, analyst following, and private information gathering (e.g., Beyer et al., 2010; Frankel and Li, 2004).

${ }^{2}$ In particular, Armstrong et al. (2010) discuss how a large body of literature argues that a firm's governance structure is, to a large extent, a choice variable and is therefore endogenous with respect to its information environment. In addition, prior research (e.g., DeFond, Hann, and Hu, 2005) argues that a firm's information environment in general, and its financial disclosure and reporting practices in particular, are also choice variables and are therefore endogenous with respect to the firm's governance structure. This makes it difficult to distinguish between a causal effect (and the direction of causality) and an association between corporate governance and firms' information environments.
} 
(e.g., Bushman et al., 2004, Warfield et al., 1995, Ajinkya et al., 2005). Accordingly, the nature of this relation is still an open empirical question that warrants further examination.

This study adds to our understanding of the relation between firms' governance structures and their information environments by examining how changes in antitakeover protection, which is an important element of firms' overall corporate governance structure, affects their information environments. The second-generation state antitakeover laws, which affected firms incorporated in the states passing these laws, were adopted in the United States starting in the mid-1980s. We use the passage of these laws as a source of exogenous variation in firms' corporate governance structures with which we identify the causal effect of a change in corporate governance on firms' information environments.

Changes in antitakeover provisions can affect a firm's information environment and the level of information asymmetry between managers and outside investors in several ways. First, antitakeover provisions can have an effect on the level of private information gathering in the capital markets (Ferreira and Laux, 2007). For example, more or stronger antitakeover provisions imply a lower probability of a takeover (Ambrose and Megginson, 1992), which provides traders with fewer incentives to collect private information for speculative purposes. Consistent with this view, Larcker and Lys (1987) document that risk arbitragers, who speculate on the likelihood of takeover, earn substantial returns, which suggests that these traders have incentives to collect and trade on the basis of private information.

In addition, changes in the degree of antitakeover protection can affect a firm's information environment by influencing the level of corporate transparency and the quality of financial information generated and provided by the firm through several channels. An increase in antitakeover provisions reduces the threat of a hostile takeover, which insulates managers 
from the disciplining effects of the market for corporate control. The increase in entrenchment might reduce managers' incentives to provide transparent information to the capital markets and other external parties (Bertrand and Mullainathan, 2003; Ferreira and Laux, 2007; Fu and Liu, 2008). Alternatively, once insulated from the threat of a takeover, managers may enjoy the socalled "quiet life" and make fewer investments. The resulting reduction in future cash flow volatility might result in improved financial statement informativeness. Moreover, managers might feel more secure about their labor market prospects and therefore become less concerned about concealing poor performance through financial reports. Finally, managers might want to voluntarily improve their financial reporting quality following the passage of the antitakeover laws to allow for better monitoring, especially if the firm seeks to raise external equity capital.

Another channel through which changes in the degree of antitakeover protection can affect a firm's information environment is their influence on the behavior of equity analysts. Analysts have incentives to gather private information, especially about important events such as mergers and acquisitions, and the passage of the antitakeover laws might reduce analysts' incentives to gather private information, which, in turn, might affect the quality of information they provide. Alternatively, if analysts serve as monitors, then an increase in antitakeover provisions might cause them to expend greater effort to collect and disseminate information.

Therefore, there are several competing predictions regarding how corporate governance mechanisms in general, and oversight from the market for corporate control in particular, may affect firms' information environments. We examine the relation between these two constructs using variation in firms' corporate governance structures that resulted from the passage of antitakeover laws by a number of U.S. states between 1985 and 1991 as a pseudo-natural experiment. An important advantage of this setting is that, unlike recent regulatory changes that 
applied to all firms at the same time, such as the Sarbanes-Oxley Act (SOX) or Regulation Fair Disclosure (Reg. FD), the passage of antitakeover laws occurred at different times in different states. ${ }^{3}$ This variation allows us to use a differences-in-differences research design, which enables a more precise identification of the causal effects of the antitakeover laws. A major limitation of studies that evaluate and analyze the economic consequences of a broad regulation such as SOX and Reg. FD is that the regulation generally applies to every firm at the same time, which makes it difficult to identify an appropriate control group that is not affected by the regulation. This makes it difficult to uniquely identify and distinguish the effect of the regulation from other contemporaneous changes that might have occurred and in turn limits researchers' ability to draw casual inferences about the effects of the regulation of interest. Our use of a differences-in-differences research design addresses these concerns by using both the same firm over time (potentially before and after the passage of antitakeover laws) and similar firms in different states at the same time (which potentially had different antitakeover laws) as the control group. This approach allows us to draw causal inferences about the effect of corporate governance on firms' information environments.

We first examine the effect of changes in state antitakeover laws on the level of information asymmetry. We find strong evidence that the level of information asymmetry significantly declined following the passage of these laws. We also find that the level of idiosyncratic volatility decreased following the passage of the laws, indicating that they led to a reduction in private information gathering. Further, we document an increase in the

\footnotetext{
${ }^{3}$ The state specific antitakeover laws did not apply to all firms at the same time but were instead passed and became effective at different times. Our empirical methodology exploits this fact and our control group is not restricted to firms in states that never pass an antitakeover law. In fact, the specific multivariate regression we discuss in Section 3 can be estimated even if all states eventually pass antitakeover laws. We implicitly treat as our control group all firms incorporated in states not passing a law at a specific time, even if they have already done so in a previous year or will pass one in the future.
} 
informativeness of financial statements. In addition, we also find a significant decline in analyst coverage following the passage of the laws, which is also consistent with the laws causing a reduction in private information gathering. Finally, we attempt to distinguish among the competing theories for why and how financial statement informativeness would change after the passage of the antitakeover laws and provide evidence suggesting that the increase in financial statement informativeness is attributable to firms that are most likely to access equity markets. In contrast, we find little support for the quiet life, career concern, and managerial entrenchment hypotheses.

The contribution of our study is threefold. First, we add to the literature that examines the relation between firms' corporate governance structures and their information environments by providing evidence on the causal relation between these two constructs. ${ }^{4}$ The extant empirical evidence is mixed and depends on the specific governance mechanism and the specific dimension of the information environment examined. One potential explanation for the conflicting evidence, and a more general concern with the existing literature, is the endogenous relation between a firm's governance structure and its information environment, since these two constructs are expected to be jointly determined (Armstrong et al., 2010). ${ }^{5}$ By using the passage of the state antitakeover laws as an exogenous increase in firms' protection from hostile takeovers, our results are less susceptible to endogeneity concerns that plague the existing literature.

\footnotetext{
${ }^{4}$ See Bushman and Smith $(2001,2003)$ and Armstrong et al. (2010) for detailed surveys of this literature.

${ }^{5}$ For example, one might predict a positive relation between the number of outside directors and a firm's financial statement transparency because outside directors require timely and reliable information to fulfill their monitoring role. A positive relation between the proportion of outside directors and the level of financial statement transparency could occur either if firms commit to providing high-quality financial disclosures in anticipation of the informational needs of their outside directors or if firms' outside directors elicit higher-quality financial information. Although both scenarios would produce a positive relation between the proportion of outside directors and financial statement transparency, only the latter scenario is one in which the firm's governance structure causes changes in its information environment.
} 
Second, in addition to examining changes in firms' information environments in general, we also examine the channels through which these changes in the overall information environment occur. Specifically, we explore the impact of the antitakeover laws on information supplied by firms and private information gathering outside of firms. This analysis is important, since information asymmetry and private information flow could change for reasons other than changes in the information that firms supply. Moreover, prior research tends to focus on only a single aspect of a firm's information environment such as voluntary disclosures (e.g., earnings forecasts), and therefore does not speak to the information environment as a whole. Therefore, the extant literature cannot speak to the net effect of corporate governance mechanisms on either the information asymmetry between managers and investors or the information asymmetry among investors.

Third, our study contributes to the literature that examines the economic consequences of the passage of state antitakeover laws. A number of studies in the law, economics, and finance literatures find that these laws have had significant economic effects. For example, prior research has documented that the antitakeover laws led to a reduction in the equity ownership of officers and directors (Cheng, Nagar, and Rajan, 2004), changes in managerial pay (Bertrand and Mullainathan, 1999, 2000; Cheng and Indjejikian, 2009), a reduction in firm leverage (Garvey and Hanka, 1999), a decline in firm productivity and profitability (Bertrand and Mullainathan, 2003), and an increase in the adoption of poison pills (Comment and Schwert, 1995). More recently, Francis et al. (2009) find that the state antitakeover laws led to a decrease in bond yields and an increase in bond prices, which they interpret as evidence that these laws reduced the agency cost of debt by shielding bondholders from expropriation in the event of a takeover. 
We add to this literature by documenting the effect of the antitakeover laws on firms' information environments.

The remainder of our paper is organized as follows. Section 2 provides institutional background on the state antitakeover laws and discusses our hypothesis development and empirical predictions. Section 3 describes our research design, our sample selection, and the measurement of key variables. Section 4 discusses our results, including a number of sensitivity analyses. Section 5 concludes the paper.

\section{Institutional Background and Hypothesis Development}

\subsection{Institutional background}

The regulation of U.S. corporate takeover activity dates to the passage of the Williams Act, a 1968 federal statute enacted to address various antitrust and antitakeover issues. Prohibiting "fraudulent, deceptive, or manipulative acts or practices in connection with any tender offer," the Williams Act called for detailed disclosure requirements, a specific antifraud system, and other explicit measures to protect the shareholders of a target company during a tender offer. A number of states followed suit by passing their own set of statutes regulating antitakeover activities, which legal commentators referred to by as the "first generation" of state antitakeover laws.

However, in 1982 (Edgar v. Mite Corp.), the Supreme Court found these first-generation laws unconstitutional, since they violated the Commerce Clause and, to a lesser extent, the Supremacy Clause of the U.S. Constitution. In response, a number of states passed the so-called "second generation" of antitakeover laws in the mid- to late 1980s, which addressed some of the issues the Supreme Court raised. In what many viewed as a surprise ruling, the Supreme Court upheld their constitutionality in 1987 in Dynamics Corp. v. CTS by ruling that state-specific 
antitakeover laws are enforceable as long as they do not prevent compliance with the original Williams Act. In particular, the second-generation antitakeover laws were deemed constitutional since they restricted the jurisdiction of the antitakeover laws to only those firms incorporated in the legislating state.

This ruling paved the way for further antitakeover legislation in the late 1980s and early 1990s, referred to as the "third generation" of antitakeover laws, which were even more stringent in regulating and constraining takeover activities. The most stringent set of second- and thirdgeneration antitakeover laws are referred to as business combination laws, which are the focus of much of the literature as well as our study.

As Cheng, Nagar, and Rajan (2004) and others discuss, the second and third generation of antitakeover laws generally relied on some combination of the following three provisions. First, control share acquisition laws provide the holders of shares not held by the acquirer the right to decide whether the acquirer's shares may vote on the takeover. Second, fair-price laws require that the acquirer pay a "fair price" for shares purchased for the takeover. Third, business combination laws prevent a potential acquirer from engaging in takeover activities for a specified period unless the target board votes otherwise. Table 1 lists the year in which the antitakeover laws became effective in each state (if any) and the number of unique firms in our sample that are incorporated in each state. In addition, we also note the provisions included in the antitakeover laws and state whether the laws in each state are considered "strong" or "weak" according to prior studies (e.g., Garvey and Hanka, 1999; Bertrand and Mullainathan 2003). We use this classification in sensitivity analyses discussed further below.

A number of studies, mostly in the finance literature, have examined the subsequent economic consequences associated with the passage of the second- and third-generation 
antitakeover laws. These studies usually fall into one of the following three categories: (1) those examining the impact on firms' stock prices, (2) those examining the impact on the frequency of takeovers, and (3) those examining the impact on various firm-specific outcomes related to investments, productivity, and other corporate finance activities. ${ }^{6}$ The collective evidence from these studies suggests that the second and third generation of antitakeover laws were effective in deterring takeovers, which resulted in entrenching management. In particular, Comment and Schwert (1995) find that takeover premiums increased following the passage of antitakeover laws, which is consistent with these laws' making takeovers more costly.

In addition, the general conclusion of these studies is that the antitakeover laws have been effective as an impediment to hostile takeovers and have, to some degree, insulated managers from the threat of hostile takeover. Although Comment and Schwert (1995) find little evidence that the antitakeover laws actually reduced the frequency of takeovers, it is important to note that examining the effect of antitakeover laws on actual takeovers is quite challenging given the relatively infrequent occurrence of hostile takeovers. In addition, Bertrand and Mullainathan (2003) also note that it is difficult to distinguish between hostile takeovers and non-hostile takeovers. However, using an extended sample period, Schwert (2000) finds that takeover activity declined after the passage of these laws.

The third group of studies examines the effect of the antitakeover laws on firm-specific characteristics and choice variables. For example, Garvey and Hanka (1999) provide evidence that firms affected by second-generation antitakeover laws reduced their leverage, and Bertrand and Mullainathan $(1999,2003)$ provide evidence on the effects of the laws on wages and firmlevel productivity. Cheng et al. (2004) find a significant reduction in the proportion of

\footnotetext{
${ }^{6}$ For a summary of the papers analyzing the stock price effects of antitakeover laws, see Easterbrook and Fischel (1991).
} 
blockholders on the board of directors as well as the stock ownership of managers. The evidence in Cheng et al. (2004) is consistent with managers' tendency to reduce their ownership of stock following the passage of antitakeover laws since they can ensure their prior level of control by holding fewer (risky) shares of their firm.

Cheng and Indjejikian (2009) examine how firms changed their CEO compensation practices following the passage of antitakeover laws and find an increase in CEO compensation and a higher sensitivity of pay to the "good luck" component of performance. Based on these findings, Cheng and Indjejikian (2009) conclude that CEO compensation practices and the disciplining effect of the market for corporate control are complementary governance mechanisms. Overall, the empirical evidence to date suggests that the second- and thirdgeneration antitakeover laws reduced the likelihood and threat of a hostile takeover.

The extant literature has also argued that the passage of antitakeover laws was an exogenous event and, as such, is a natural empirical setting for testing research questions and predictions that are otherwise limited because of the endogenous nature of firm-specific antitakeover provisions (e.g., poison pills and change in control provisions). However, there might be some concerns that the passage of these laws was not entirely exogenous. Romano (1987) specifically addresses this concern by analyzing the political context in which state antitakeover laws were passed. An important finding by Romano (1987) is that antitakeover laws were almost always exclusively promoted by a specific company that was under the threat of takeover and were not a result of an organized effort by firms.

Using the law that was passed in Connecticut as an example, Romano concludes that "the spur behind the passage of the Connecticut law was not a broad-based political coalition. Rather, the bill was promoted by a corporation incorporated in Connecticut, the Aetna Life and Casualty 
Insurance Company (Aetna)." In Arizona, the takeover bill was referred to as "the Greyhound Bill” since Greyhound executives were its exclusive promoter. In Missouri, Trans World Airlines promoted the antitakeover bill while battling activist investor Carl Icahn. These examples suggests that the passage of the antitakeover laws was an exogenous event to the majority of firms incorporated in the state and seems to be unrelated to these firms' information environments. In other words, none of the evidence in the literature suggests that the reason for lobbying was an actual or anticipated change in firms' information environments.

Nevertheless, in sensitivity analyses reported below, we follow Bertrand and Mullainathan (2003) and estimate our primary models in event time surrounding the passage of the antitakeover laws. These results speak to the potential effect of lobbying (or reverse causality) on our reported results. Similar to Bertrand and Mullainathan (2003), we find that the effect of the antitakeover laws on firms' information environment occurs following their passage and not before, which helps to allay concerns about their validity as a source of exogenous variation in firms' corporate governance structures.

\subsection{Hypothesis development}

\subsubsection{Antitakeover laws, information asymmetry, and private information gathering}

Our empirical predictions about the effect of the antitakeover laws on firms' information environments are based on both theory and recent empirical evidence. Two sets of economic theory are particularly relevant in this regard. First, Stein (1988) and Shleifer and Summers (1988) suggest that since antitakeover laws reduce takeover pressure, they should reduce managerial myopia, which could, in turn, increase the quality of financial reporting. Another set of theories (e.g., Edlin and Stiglitz, 1995; Shleifer and Vishny, 1989) suggests that an opaque information environment can serve as a form of takeover defense and, consequently, might 
reduce takeover pressure. Therefore, if opacity in firms' information environments and antitakeover laws serve as substitute mechanisms that protect firms from takeover, a change in the antitakeover laws might be expected to affect firms' information environments. This change can take place along several dimensions, including (1) the degree of information asymmetry between managers and outsiders, (2) information asymmetry among investors, which manifests in the form of information-based trading, (3) private information flow and gathering activities, and (4) the informativeness of firms' financial statements.

The magnitude and direction of the effect of the antitakeover laws on information asymmetry is an empirical question. In contrast to information asymmetry for which the predicted relation is ambiguous, a reduction in the threat of takeovers due to the state antitakeover legislation should lead to less speculative trading and private information gathering (e.g., Ferreira and Laux, 2007). Accordingly, we predict a decrease in private information gathering after the passage of the laws.

\subsubsection{Antitakeover laws and financial statement informativeness}

There are several alternative channels through which the informativeness of financial statements might change following the passage of the antitakeover laws. First, since antitakeover laws shield managers from the threat of takeover, they result in greater managerial entrenchment and agency costs. Prior studies have argued and provided evidence that suggests that entrenched managers are associated with lower levels of transparency (e.g., Francis et al., 2005; Shleifer and Vishny, 1989; Hermalin and Weisbach, 2008). Accordingly, the managerial entrenchment view predicts that managers will withhold information after the passage of the antitakeover laws and, consequently, their firms will have lower-quality financial reporting. 
A second view posits that antitakeover laws insulate managers from the threat of a takeover, which allows them to more easily pursue the "quiet life" by making fewer investments and pursuing fewer of their firms' growth options (e.g., Bertrand and Mullinathan, 2003; Giroud and Mueller, 2010). To the extent that managers pursue the quiet life following the passage of the antitakeover laws, we should observe an increase in the average quality of their firms' financial reporting, since there will be less uncertainty about and variability in their future cash flows. Moreover, the quiet life channel also generates the cross-sectional prediction that firms at which managers pursue the quiet life following the passage of the state antitakeover laws should experience an improvement in financial reporting quality, while those firms where managers do not pursue the quiet life should not experience a similar improvement in their financial reporting quality.

A third possibility is that the removal of the threat of takeover and the accompanying disciplinary forces of the market for corporate control reduces managers' concerns for their future labor market prospects (Stein, 2003). This view predicts that managers will become less concerned about concealing poor performance and may, in fact, provide more transparent information. Consequently, managers might choose to simply report their firm's true performance without distortion, regardless of whether it is good or bad, which would result in improved financial reporting quality. This channel predicts that managers with low levels of career concerns before the passage of the antitakeover laws will benefit less (in terms of increased job security) from the passage of the antitakeover laws and that firms with such managers should therefore not experience a change in financial reporting quality.

A fourth possibility is that, since the market for corporate control serves as a monitoring mechanism (e.g., Manne, 1965; Williamson, 1983), the passage of the antitakeover laws results 
in less managerial monitoring. If financial statements assist the firm's other stakeholders (e.g., analysts, institutional owners, shareholders, and regulators) in their monitoring activities, then managers might want to voluntarily improve their financial reporting quality following the passage of the antitakeover laws to allow for better monitoring (i.e., to restore the overall level of external monitoring back to its previous level). For example, if a firm is more dependent on the equity market for capital, then it will now have an incentive to be more transparent to signal its type to shareholders (e.g., Ruland et al., 1990; Marquardt and Weidman, 1998; and Lang and Lundholm, 2000). We refer to this potential effect as the signaling channel, and it predicts that firms that are more dependent on equity financing are the ones that experience the greatest improvement in their financial reporting quality following the passage of the antitakeover laws.

An alternative way to characterize the relation between antitakeover legislation and firms' reporting practices is to view the evolution of financial reporting practices and the strength of the market for corporate control as jointly determined. In this case, a shock to the strength of the market for corporate control should result in changes to the level of financial reporting. However, the direction of the change is ambiguous, because financial reporting is both an input to, and an outcome of, different governance mechanisms. Since increased transparency is one mechanism by which managers can ex ante commit against taking actions that are detrimental to shareholders and other parties that contract with the firm (e.g., Armstrong et al., 2010), one can argue that the passage of antitakeover laws should result in an increase in corporate transparency. Alternatively, since the antitakeover laws insulate managers from discipline from the market for corporate control, they might instead reduce their incentives to be transparent. Given these different predictions, the effect of antitakeover laws on financial statement informativeness is, to a large extent, an empirical question. 


\subsubsection{Antitakeover laws and analyst behavior}

A final channel through which the state antitakeover laws can affect firms' information environments is through their effect on the level of analyst coverage and their forecast properties. On one hand, as previously discussed, a reduction in the threat of takeover reduces incentives for private information gathering about the probability of takeover, which, in turn, reduces the amount of speculative trade. Since analysts have incentives to gather private information, especially about important events such as mergers and acquisitions and takeovers, the passage of the antitakeover laws should reduce analysts' incentives to gather private information, and, consequently, analysts may reduce their coverage of firms. On the other hand, if analysts serve as a mechanism to monitor managers, then analyst coverage may increase following the passage of antitakeover laws (e.g., Yu, 2008). ${ }^{7}$

We also predict that analyst earnings forecast errors will change following the passage of the laws. Information provided by firms is an important input to analysts' forecasting models. Accordingly, if firms provide better information in response to the laws, then we expect analyst forecast errors to decrease. Alternatively, if firms provide less transparent information in response to the laws, we expect analyst earnings forecast errors to increase.

\footnotetext{
${ }^{7}$ The role of financial analysts in corporate governance is not clear ex ante. Although analysts might serve as monitors of managers, they might also put more pressure on managers to engage in earnings management to meet or beat forecasts. Yu (2008) examines this possibility empirically and finds that firms followed by more analysts engage in less earnings management. This evidence is consistent with a monitoring role of analysts, which might be expected to change after the passage of antitakeover laws, since these laws reduced the efficacy of an important monitoring mechanism (i.e., the market for corporate control).
} 


\section{Research Design, Sample Selection, and Variable Measurement}

\subsection{Research design}

We use the passage of state antitakeover laws as a source of exogenous variation in an important corporate governance mechanism with which we identify the effect of governance on firms' information environments. Although we use a number of alternative proxies for the information environment, our basic research design entails estimating the following equation:

$$
y_{i, j, t}=\alpha_{i}+\lambda_{t}+\beta_{1} \text { ANTITAKEOVER }_{j, t}+\gamma X_{, i, j t}+\varepsilon_{, i, j t}
$$

where $i$ indexes firms, $j$ indexes state of incorporation and $t$ indexes time, $y$ is the dependent variable of interest and represents one of the proxies for the information environment, $\alpha$ is the firm fixed effect, $\lambda$ is the time fixed effect, ANTITAKEOVER is an indicator variable that takes a value of one if antitakeover laws are in effect in state $j$ during year $t$ and zero otherwise, and $\mathbf{X}$ is a vector of control variables.

Equation (1) essentially represents a differences-in-differences specification that is similar to the one in Bertrand and Mullainathan (2003). As Bertrand, Duflo, and Mullainathan (2004) discuss, the differences-in-differences approach has become an increasingly popular research design for identifying causal effects. To better understand the specification in Equation (1), consider the following example within a potential outcomes framework. ${ }^{8}$ Let $y_{1 i, j, t}$ denote the information environment of firm $i$, incorporated in state $j$, during period $t$ if there are antitakeover laws in effect in the state of incorporation during the period, and let $y_{0 i, j, t}$ denote the

\footnotetext{
${ }^{8}$ Following Rubin (1974), this framework is referred to as the potential outcomes framework because, for any firm, it is possible to observe only one outcome and not the other. For example, a researcher can observe the information environment of a firm incorporated in a state that passed antitakeover laws but cannot observe the information environment of the same firm incorporated in the same state that did not pass antitakeover laws at the same point in time. The latter outcome that did not occur is referred to as the "counterfactual" outcome, and its unobservability creates an identification problem that precludes determining the causal effect of the antitakeover laws (or some other treatment of interest) for a specific firm. A differences-in-differences research design therefore imposes identifying assumptions, which are necessary to document causal effects.
} 
information environment of firm $i$, incorporated in state $j$, during period $t$ if there are no antitakeover laws in effect in the state of incorporation during the period. These are referred to as potential outcomes, because a given state can either have passed or not have passed antitakeover laws at time $t$. Therefore, for any firm, it is possible to observe only one or the other, but not both (e.g., $y_{1 i, j, t}$ is observed for firm $i$ if it is incorporated in Pennsylvania (PA) in 1998, since antitakeover laws were in effect in that state at that time as indicated in Table 1, but $y_{0 i, j, t}$ would have been observed if Pennsylvania did not have antitakeover laws in effect during 1998). Assuming that $E\left[y_{1 i, j, t}-y_{0 i, j, t} \mid j, t\right]$ is constant and denoted by $\beta$, firm i’s observed information environment, $y_{i, j, t}$, can be written as follows: ${ }^{9}$

$$
y_{i, j, t}=\alpha_{i}+\lambda_{t}+\beta_{1} \text { ANTITAKEOVER }_{j, t}+\varepsilon_{, i, j t}
$$

We can now examine the difference in information environments of firms incorporated in the state of Pennsylvania around the passage of its antitakeover laws in 1987 as

$$
E\left[y_{i, j, t} \mid j=P A, t=1988\right]-E\left[y_{i, j, t} \mid j=P A, t=1987\right]=\lambda_{1988}-\lambda_{1987}+\beta
$$

And the difference in the information environment of firms incorporated in another state, say, Vermont (VT), which did not have antitakeover laws in places during that period, as:

$$
E\left[y_{i, j, t} \mid j=V T, t=1988\right]-E\left[y_{i, j, t} \mid j=V T, t=1987\right]=\lambda_{1988}-\lambda_{1987}
$$

So, the population difference-in-differences becomes:

$$
\begin{aligned}
& \left\{E\left[y_{i, j, t} \mid j=P A, t=1988\right]-E\left[y_{i, j, t} \mid j=P A, t=1987\right]\right\}- \\
& \left\{E\left[y_{i, j, t} \mid j=V T, t=1988\right]-E\left[y_{i, j, t} \mid j=V T, t=1987\right]\right\}=\beta
\end{aligned}
$$

which is the causal effect of the antitakeover law of interest in our study. In particular, the first difference compares the information environment of firms incorporated in Pennsylvania before and after the passage of the antitakeover laws and the second difference compares the change in

\footnotetext{
${ }^{9}$ Note that Equation (2) is identical to Equation (1) but without the control variables.
} 
the information environment of firms incorporated in Vermont (which did not have antitakeover laws in place) during the same period. This approach illustrates that the identifying assumption in this research design is that trends in the outcome of interest would have been the same in both states absent the passage of antitakeover laws. In other words, it is the trend in the outcome variable of interest in states that did not have antitakeover laws in effect during a given period that serves as the counterfactual outcome with which we identify the causal effect of the state antitakeover laws on firms' information environments.

Although a simple comparison of average differences as in Equation (5) is one way to implement a differences-in-differences research design, it does not allow for control variables that are likely to affect firms' information environments, nor is it amenable to examining multiple states that might have passed antitakeover laws at different times. We therefore estimate the regression analog that is given by Equation (1), which allows for control variables and for different states that passed antitakeover laws at different times. As Bertrand and Mullainathan (2003) note, the staggered passage of the antitakeover laws means that our control group is not restricted to states that never passed antitakeover laws. Instead, the control group includes all the firms incorporated in states not passing an antitakeover law at time $t$, even if their state of incorporation has already passed, or will pass (sometime after time $t$ ), antitakeover laws.

We also follow Bertrand and Mullainathan (2003) and control for local and industry shocks by including a full set of time-varying industry-year and state-year controls, which are computed as the mean of the dependent variable in the firm's three-digit SIC industry and state of incorporation, respectively, in a given year, excluding the firm itself. Controlling for local and industry effects helps to separate out the effects of industry and geographic shocks that are contemporaneous with the antitakeover laws from the effects of the laws themselves. Consistent 
with Bertrand and Mullainathan (2003), we also add firm and year fixed effects to control for time and year effects that are likely to be present.

Finally, we follow Bertrand, Duflo, and Mullainathan (2004) and Bertrand and Mullainathan (2003) and report standard errors that are clustered by the state of incorporation. Together with the firm and time fixed effects, this approach accounts for correlations of the error terms (1) across different firms in a given state of incorporation and year (i.e., cross-sectional correlation), (2) across different firms in a given state of incorporation over time (i.e., acrossfirm serial correlation), and (3) within the same firm over time (i.e., within-firm serial correlation) (Petersen, 2009).

\subsection{Sample selection}

Our sample draws from Compustat, CRSP, Thomson Financial Insider Filings, and I/B/E/S, as well as the Institute for the Study of Security Markets (ISSM) and the Trades and Automated Quotes (TAQ) databases. Because the required variables differ across our tests, we require only the availability of the necessary variables for a given test. This approach ensures that we use the largest sample available for each test. However, we also conduct a sensitivity analysis using the sample that results from the intersection of all variables, and we find that our results continue to hold. In addition, because the constitutionality of second-generation state antitakeover laws was uncertain until 1987 (i.e., the Supreme Court ruling in the case of CTS vs. Dynamics Corp.), we examine the sample between 1987 and $2000 .^{10}$

\subsection{Variable measurement}

\subsubsection{Information asymmetry}

We use three proxies to capture information asymmetry. First, following prior literature (e.g., Brennan and Subramanyam, 1996), we use the adverse selection component of the bid-ask

\footnotetext{
${ }^{10}$ Our results are similar when we use an expanded sample period from 1985 and 2000.
} 
spread. This variable measures the extent to which prices are affected by unexpected order flow and is increasing in the level of information asymmetry among investors. We estimate the adverse selection component of the bid-ask spread, LAMBDA, following Madhavan, Richardson, and Roomans (1997) as modified by Armstrong, Core, Taylor, and Verrecchia (2011) to take into account cross-sectional differences in firm size. To estimate $L A M B D A$, we gather trade-bytrade and quote data from the ISSM and TAQ databases. We match trades and quotes using the Lee and Ready (1991) algorithm with a five second lag to infer the direction of the trade (i.e., buy or sell). Once trades are classified as either buyer- or seller-initiated, we estimate the following firm-specific regression using all transactions available during the month:

$$
\Delta p_{t} / p_{t-1}=\psi \Delta D_{t}+\lambda\left(D_{t}-\rho D_{t-1}\right)+u_{t},
$$

where $p_{t}$ is the transaction price, $D_{t}$ is the sign of trade ( +1 if buy and -1 if sell), and $\rho$ is the AR(1) coefficient for $D_{t}$. We measure $L A M B D A(\lambda)$ once a year in March, using all intraday data for that month to estimate Equation (6) for each firm in the sample.

Our second measure of information asymmetry is the Probability of Informed Trade (PIN) measure developed by Easley et al. (2002). This measure was obtained from Soeren Hvidkjaer's website and is available annually each December. PIN has been widely used in recent studies as a proxy for information asymmetry (e.g., LaFond and Watts, 2008; Mohanram and Rajgopal, 2009; Armstrong, Core, Taylor, and Verrecchia, 2011).

For our third measure, we use the intensity of insider trades to capture the degree of information asymmetry that exists between insiders and outsiders. We follow prior literature (Lakonishok and Lee, 2001; Frankel and Li, 2004) and compute the net purchase ratio (NPR) to measure the direction of insider trading (i.e., whether insiders are buying or selling) during a given year. $N P R$ is computed by dividing the net purchases (i.e., shares purchased less shares 
sold) by an insider during a given year by the total number of insider transactions over the same period. We use Thomson Financial insider-trading data to construct this measure.

\subsubsection{Private information gathering}

Following Ferreira and Laux (2007), we use idiosyncratic volatility, SIGMA, as a proxy for private information gathering. We measure SIGMA for each firm, each month, by estimating the following regression of daily stock returns on the four Fama-French factors.

$$
\operatorname{Re} t_{i, d}=\alpha_{i}+\beta_{i, M K T} M K T+\beta_{i, S M B} S M B+\beta_{i, H M L} H M L+\beta_{i, U M D} U M D+\varepsilon_{i}
$$

where Ret is the return for stock $i$ in excess of the risk-free rate on day $d$, and $M K T, S M B, H M L$, and $U M D$ are the four Fama-French factors. We then define each firm's relative idiosyncratic volatility, or SIGMA, as $1-R^{2}$, where $R^{2}$ is obtained from the above firm-specific regression. Given the bounded nature of $R^{2}$, we use the logistic transformation of SIGMA in our empirical tests.

This measure is well established in the corporate finance literature and is based on strategic trading models and the associated empirical evidence that establishes that informed trade induces idiosyncratic volatility in stock returns (e.g., Glosten and Milgrom, 1985; French and Roll, 1986). In addition, Roll (1988) focuses specifically on idiosyncratic volatility, providing evidence that idiosyncratic price changes mainly reflect private information being incorporated into stock prices by informed trading rather than public information. Accordingly, idiosyncratic volatility is a suitable summary measure of the flow of private information about the firm.

\subsubsection{Financial statement informativeness}

We use two alternative proxies to examine the effect of the antitakeover laws on the degree of financial statement informativeness. First, we employ a measure of the value relevance 
of financial statements (e.g., Francis and Schipper 1999; Frankel and Li, 2004), RSQ, which is measured as the adjusted- $\mathrm{R}^{2}$ from the following firm-specific time-series regression:

$$
P_{i, t}=\beta_{0 i}+\beta_{1 i} E_{i, t}+\beta_{2 i} B V_{i, t}+\varepsilon_{i, t}
$$

where $P_{i, t}$ is the price per share of firm $i$ three months after fiscal year end $t, E_{i, t}$ is the earnings per share of firm $i$ during year $t$, and $B V_{i, t}$ is the book value per share of firm $i$ at the end of year $t$. We estimate Equation (8) as a rolling regression from time $t-10$ to $t$ and require that firms have a minimum of five annual observations to be included in the sample.

One issue with this proxy is that it is based on market price and therefore may be affected by changes to price dispersion after the passage of antitakeover laws that are unrelated to the informativeness of either earnings or book value of equity (i.e., financial statement variables). In other words, the removal of the threat of a takeover following the passage of the antitakeover laws results in less uncertainty about firms' future operations and cash flows, which might produce a mechanical improvement in firms' financial reporting quality.

We address this concern in two ways. First, we examine whether this mechanical relation between $R S Q$ and probability of takeover exists. We do this by first estimating the ex ante probability of takeover for each firm-year in our sample period, which is calculated as the predicted value from the logistic regression specified in Cremers, Nair, and John (2009). ${ }^{11}$ We then group firm-years into terciles based on their probability of takeover and designate these

\footnotetext{
${ }^{11}$ In particular, we estimate a logistic regression of the probability of takeover: $\operatorname{Pr}($ Takeover $=1)=f(Q, P P E$, Industry, Cash, Firm Size, Block, Leverage, ROA, Year Indicators). Takeover is an indicator that takes a value of one if the firm was the target of a hostile takeover during the year and zero otherwise where takeovers are identified from the SDC database. $Q$ is the ratio of the market-to-book value of assets where the market value of assets is defined as the book value of total assets plus the market value of common stock minus the book value of common equity and deferred taxes. PPE is the ratio of property, plant, and equipment to total assets. Industry is an indicator that takes a value of one if there was a takeover in the firm's industry (based on the Fama-French 48 industry classifications) during the prior year and zero otherwise. Cash is the ratio of cash and short-term investments to total assets. Firm Size is the natural logarithm of the firm's market capitalization. Block is an indicator that takes a value of one if at least one institutional investor holds more than $5 \%$ of the firm's shares and otherwise. Leverage is the ratio of debt to total assets. ROA is the ratio of income before extraordinary items to average total assets. Year Indicators are also included in the specification. The variables $Q, P P E$, Cash, Leverage, and ROA are industry adjusted based on the annual industry average value.
} 
groups as having either a low, medium, or high probability of takeover. If the mapping of earnings and book value of equity into price is affected by the probability of a takeover, then the $R S Q$ measure should be different across these three groups (i.e., the $R S Q$ measure should differ based on differences in the probability of takeover). In untabulated results, we find that the mean $R S Q$ is not significantly different (based on an F-test) across the three terciles, which suggests that the mapping of earnings and book value of equity into price is not different for firms with different probabilities of takeover. This finding mitigates concerns that the RSQ measure of financial statement informativeness exhibits a mechanical relation with the probability of takeover and, therefore, the antitakeover laws.

Second, we use an alternative measure of financial statement informativeness, $E Q$, which is based on the association between accruals and cash flows, and does not rely on the relation between financial statement variables and stock prices. ${ }^{12} \mathrm{~A}$ larger deviation between accruals and cash flows is interpreted as lower quality of accounting information. Following Barth et al. (2001), we decompose total accruals into their primary components and examine how well they predict future cash flows from operations. Our empirical measure is based on the absolute value of the residuals from the following model, estimated annually for each industry based on Fama and French (1997) 48-Industry Classification:

$$
\begin{aligned}
& C F_{i, t+1}=\phi_{1}+\phi_{2} C F_{i, t}+\phi_{3} \Delta A R_{i, t}+\phi_{4} \Delta I N V_{i, t}+\phi_{5} \Delta A P_{i, t} \\
& +\phi_{6} D E P R+\phi_{7} A M O R T+\phi_{8} O T H E R+\varepsilon_{i t}
\end{aligned}
$$

\footnotetext{
${ }^{12}$ Although measures of financial statement informativeness that are not based on market price (e.g., $E Q$ ) should be less susceptible to concerns about a potential mechanical relation with the probability of takeover, there is still the possibility that such a relation exists. For example, takeovers give rise to goodwill, and any associated future writeoffs could weaken the relation between current earnings and future cash flows. Further, the coefficient on $A M O R T$ will be affected. Therefore, we repeat all of our tabulated analyses that use $E Q$ as the measure of financial statement informativeness after eliminating any firm-years that had a merger or acquisition in the previous five years. We find that our results are unchanged, which also allays concerns about a mechanical relation between the probability of takeover and $E Q$ driving our results.
} 
where $C F$ is net cash flow from operating activities (Compustat Data308) less the accrual portion of the extraordinary items and discontinued operations reported on the statement of cash flows (Compustat Data124), $\triangle A R$ is the change in accounts receivable per the statement of cash flows (Compustat Data302), $\triangle I N V$ is the change in inventory per the statement of cash flows (Compustat Data303), $\triangle A P$ is the change in accounts payable per the statement of cash flows (Compustat Data304), DEPR is depreciation expense (Compustat Data103), and AMORT is the amortization expense (Compustat Data65). OTHER is the net of all other accruals calculated as $E A R N-(C F+\triangle A R+\triangle I N V-\triangle A P-D E P R-A M O R T)$, where EARN is income before extraordinary items and discontinued operations (Compustat Data18).

\subsubsection{Analyst Behavior}

We examine changes in (1) the extent of analyst forecast coverage, COVERAGE, (2) disagreement among analysts' annual EPS forecasts, DISPERSION, and (3) the earnings forecast error, $A F \_E R R O R$, based on annual EPS forecasts. We measure COVERAGE as the number of estimates in the most recent annual EPS forecast before the fiscal year end. We measure DISPERSION as the standard deviation of the most recent annual EPS forecast scaled by the mean estimate of the last annual EPS forecast before the fiscal year end. We measure $A F \_E R R O R$ as the absolute value of the difference between mean EPS estimate and the actual EPS scaled by firm size, which is measured using the natural logarithm of total assets. All analyst data are obtained from I/B/E/S. 


\section{Results}

\subsection{Antitakeover laws and information asymmetry}

Table 3 presents the results of the effects of the antitakeover laws on firms' information environments using three alternative information asymmetry proxies. ${ }^{13}$ As discussed in the previous section, we consider $L A M B D A$ and $P I N$ to be measures of information asymmetry among investors and $N P R$ to be a measure of information asymmetry between insiders and outsiders. ${ }^{14}$ In all three columns, we find that the estimated coefficient on ANTITAKEOVER is negative and significant, indicating that information asymmetry among investors and information asymmetry between insiders and outsiders both declined following the passage of the antitakeover laws.

An additional variable of interest is idiosyncratic volatility, since this variable captures the flow of private information to the capital markets (Roll, 1988; Ferreira and Laux, 2007). Private information flow is an important determinant of information asymmetry, and higher idiosyncratic volatility indicates more private information flowing into stock prices, resulting in a reduction in information asymmetry. As previous research suggests (e.g., Ferreira and Laux, 2007), takeover activity creates incentives to collect private information, which, in turn, leads to higher idiosyncratic volatility. The results in the last column of Table 3 indicate that private information flow (measured by SIGMA) decreased following the passage of the antitakeover laws. This finding implies that private information gathering decreased following the passage of

\footnotetext{
${ }^{13}$ It is important to note that firms may have responded to the passage of the antitakeover laws with changes in other governance mechanisms to restore the overall corporate governance system to its optimal level. For example, following the passage of antitakeover laws, a firm might have increased the proportion of outside directors on its board to facilitate better monitoring of management (Williamson, 1983). It is also important to note that such a change in alternative governance mechanisms does not limit our analysis and inferences, because we are interested in documenting the net effect of the antitakeover laws on firms' information environments, regardless of the channel through which these effects came about.

${ }^{14}$ Although information asymmetry between insiders and outsiders and information asymmetry among investors are two different constructs, they are likely to be correlated (Cai et al., 2009). The (Pearson) correlations in our sample are 0.14 between PIN and NPR, 0.40 between LAMBDA and PIN and 0.08 between NPR and PIN.
} 
these antitakeover laws, possibly because the lower probability of a takeover associated with the laws reduced the gains to collecting private information on the likelihood of a takeover (Ferreira and Laux, 2007). Moreover, when considered along with the previous evidence that information asymmetry decreased following the passage of these laws, it suggests that a reduction in private information gathering was not the source of the observed decrease in information asymmetry.

Prior studies that use the passage of state antitakeover laws as a source of exogenous change to firms' governance structures entertain the possibility that the passage of these laws was not exogenous, but was instead the result of lobbying by firms that were thought to benefit from their enactment (Bertrand and Mullainathan, 2003). Although including the state-year and industry-year controls mitigates concerns that the passage of the antitakeover laws was the outcome of broad-based lobbying at the state and industry level, it is possible that lobbying occurred at the state-of-incorporation level and that the statutes adopted depended directly on the common economic prospects and information environments of all firms in the state. We next consider the issue of reverse causality.

Following Bertrand and Mullainathan (2003), we replace the ANTITAKEOVER indicator in Equation (1) with the following four indicator variables: ANTITAKEOVER(-1), ANTITAKEOVER(0), ANTITAKEOVER(1), and ANTITAKEOVER(2+), where ANTITAKEOVER $(-1)$ is an event time indicator that equals one if the firm is incorporated in a state one year before the passage of its antitakeover laws, ANTITAKEOVER(0) is an indicator that equals one if the firm is incorporated in a state during the year of the passage of its antitakeover laws, and ANTITAKEOVER(1) and ANTITAKEOVER(2+) are indicators that equal one if the firm is incorporated in a state in the year following the passage of its antitakeover laws or two or more years following the passage of its antitakeover laws, respectively. If the 
antitakeover laws were passed in response to political pressure of a broad coalition of firms, then the "effect" of the laws should precede their passage. Alternatively, if their passage was a relatively exogenous event for most firms (as argued by Romano, 1987 and others), then their effect should be detected only after they became effective. In other words, if the laws were exogenous, we should find significant coefficients only for ANTITAKEOVER(0), ANTITAKEOVER(1), and ANTITAKEOVER(2+). The results in Table 4 reveal that the effect of the laws never preceded their passage using any of the three measures of information asymmetry or idiosyncratic volatility. The results presented in Table 4 are consistent with prior literature and suggest that the passage of the antitakeover laws was relatively exogenous rather than in response to lobbying by a broad subset of the firms in our sample.

\subsection{Antitakeover laws and financial statement informativeness}

Our first set of results indicates that information asymmetry decreased following the passage of the antitakeover laws. In this section, we examine the extent to which public information provided by firms contributed to this decrease by examining the effect of antitakeover laws on financial statement informativeness. We first examine whether the price informativeness of financial statements, defined as the adjusted- $R^{2}$ from a firm-specific timeseries regression of price on earnings and book value of equity, changed following the enactment of the antitakeover laws. Columns (1) and (2) of Table 5 show that the coefficient on ANTITAKEOVER is positive and significant, which indicates that the price informativeness of financial statements (i.e., earnings and book value) increased following the passage of the antitakeover laws.

As noted earlier, one concern with the preceding analysis is that it relies on a stock pricebased measure and therefore may be affected by changes to price dispersion after the passage of antitakeover laws that is unrelated to the informativeness of either earnings or book value of 
equity. ${ }^{15}$ We address this concern by using Barth et al.'s (2001) measure of earnings quality, EQ, as an alternative proxy for financial statement informativeness. Columns (3) and (4) of Table 5 show that the coefficient on ANTITAKEOVER is negative and significant, indicating that financial reporting informativeness increased following the passage of the antitakeover laws. Collectively, the evidence in Table 5 indicates that the informativeness of financial statements (i.e., public information provided by the firms) increased following the passage of the antitakeover laws.

\subsection{Antitakeover laws and analyst behavior}

Another channel through which antitakeover laws may affect the level of information asymmetry is the activity of financial analysts. Analysts collect private information as well as interpret public information and therefore have a direct effect on the level of information asymmetry between the firm and outsiders. We therefore examine the effect of state antitakeover laws on analyst coverage as well as the properties of analyst earnings forecasts. In particular, we examine changes in (1) the extent of analyst forecast coverage, COVERAGE, (2) disagreement among analysts' annual EPS forecasts, DISPERSION, and (3) the earnings forecast error, $A F \_E R R O R$, based on annual EPS forecasts.

The first column of Table 6 indicates that analyst coverage declined following the enactment of antitakeover laws. The second and third columns show that the size of the forecast error and level of disagreement among analysts also declined following the passage of the antitakeover laws. Collectively, this evidence indicates that although the number of analysts declined following the passage of antitakeover laws, the extent of their disagreement declined and their forecast accuracy improved. This evidence also suggests that the reduction in the level of information asymmetry documented in our previous tests is not a result of increased analyst

\footnotetext{
${ }^{15}$ For example, less speculative trading may reduce the dispersion of stock prices.
} 
coverage, but is instead consistent with firms supplying higher-quality financial information, which reduced disagreement among analysts and improved the accuracy of their forecasts. This finding is consistent with our prior results on the various measures of private information flow.

\subsection{Testing competing hypotheses related to financial statement informativeness}

As discussed in Section 2.2.2, to discriminate among the competing explanations for why firms' quality of financial reporting might have changed following the passage of the antitakeover laws, we estimate a number of additional cross-sectional tests. First, we identify firms that pursued the so-called "quiet life" following the passage of antitakeover laws. Following prior literature (e.g., Giroud and Mueller, 2010) we use several alternative measures of investment to determine whether each firm-year had positive or negative industry- and stateadjusted growth in (1) assets (Compustat data6), (2) PP\&E (Compustat data8), (3) COGS (Compustat data41), and (4) advertising expenses (Compustat data45). Managers of firms with negative industry- and state-adjusted growth in these variables are classified as pursuing the quiet life. We then estimate Equation (2) with the financial statement informativeness variable $E Q$ as the dependent variable for each of these subsamples. Results presented in Table 7 indicate that firms in both subsamples experienced a significant improvement in EQ following the passage of the antitakeover laws, which suggests that managers' pursuit of the quiet life does not appear to be responsible for the observed improvement in firms’ financial reporting quality. ${ }^{16}$

Our next test examines whether the career concerns view accounts for the observed improvement in financial statement informativeness. We use a firm's ex ante probability of takeover as a proxy for the level of career concerns that managers face before passage of the antitakeover laws. Higher ex ante probability of takeover suggests a higher level of career

\footnotetext{
${ }^{16}$ In untabulated tests, we find similar results when $L A M B D A$ is the dependent variable. This result is consistent with an improvement in the aggregate information environment of both subsamples of firms following the passage of the antitakeover laws.
} 
concern. ${ }^{17}$ Specifically, we test for evidence of the career concerns explanation by partitioning our sample based on firms' ex ante probability of takeover, PROBABILITY, estimated as the predicted value from the logistic regression specified in Cremers et al. (2009). The results are presented in Table 8 and show that ANTITAKEOVER is negative and significant in both the subsample of firms with a relatively low probability of takeover (and, therefore, the managers of which are not expected to benefit as much from the passage of the antitakeover laws) and the subsample of firms with a relatively high probability of takeover. Overall, the results in Table 8 suggest that the improvement in financial reporting quality was not due to changes in managers' career concerns that might have resulted from the passage of the antitakeover laws.

Finally, to test the signaling hypothesis that firms supply higher-quality financial statements following the passage of the antitakeover laws to signal their "type" to shareholders, we require a measure of firms' dependence on the equity market as a source of financing. We follow Fama and French (2008) and Chen, Novy-Marx, and Zhang (2010) and calculate net equity issues as the ratio of the split-adjusted shares outstanding at the end of fiscal year $t-1$ to the split-adjusted shares outstanding at the end of fiscal year $t-2$. We then classify firms that have a net equity issuance value greater than or equal to one as "Net Equity Issuers." We then estimate Equation (2) with the financial statement informativeness variable $E Q$ as the dependent variable for each of these subsamples. The results are presented in Table 9 and show that the improvement in financial reporting quality $(E Q)$ occurred only in the subsample of firms that are net equity issuers and are therefore more likely to depend on equity markets as a source of capital. This result is consistent with Ruland et al. (1990), Marquardt and Weidman (1998), and Lang and Lundholm (2000), who present evidence that firms accessing capital markets tend to

\footnotetext{
${ }^{17}$ An alternative proxy for career concern would be CEO's age. However, we are unable to obtain this information for the sample period in this study.
} 
provide higher-quality information. In the context of our study, this result suggests that firms that are more likely to issue equity are the firms that account for the average improvement in financial reporting quality following the passage of the state antitakeover laws.

\subsection{Additional analyses}

\subsubsection{Alternative specification for financial statement informativeness}

In this section, we adopt an alternative research design that is different from the differences-in-differences approach that we used to examine the effect of the antitakeover laws on financial statement informativeness. Specifically, we examine the differential informativeness of earnings before and after the passage of the antitakeover laws by estimating the slope coefficients from a regression of annual stock returns on annual earnings. Following Easton and Harris (1991), we estimate the following equation: ${ }^{18}$

$$
\operatorname{Ret}_{i j t}=\alpha+\beta_{1} \operatorname{EARN}_{i t}+\beta_{2} \operatorname{EARN}_{i t} * \text { ANTITAKEOVER }_{j t}+\gamma X_{i t}+\varepsilon_{i j t}
$$

where $i$ indexes firms, $j$ indexes state of incorporation, $t$ indexes time, and Ret is the 15-month cumulative raw return during the interval that begins three months following the end of fiscal year $t-1$ and ends six months after the end of fiscal year $t .{ }^{19}$ ANTITAKEOVER is an indicator variable that takes a value of one if antitakeover laws are in effect in state $j$ during year $t$ and zero otherwise, $\mathbf{X}$ is a vector of control variables, and $E A R N$ is earnings (Compustat data18) for fiscal year $t$ scaled by assets (Compustat data6) at the end of fiscal year $t-1$. The coefficient of interest is $E A R N^{*} A N T I T A K E O V E R$, which captures the effect of the antitakeover laws on the earningsreturn relation. The results presented in Column (1) of Table 10 indicate that

\footnotetext{
${ }^{18}$ Our results are similar if we include both levels as well as changes in earnings.

${ }^{19}$ We obtain similar results if we cumulate returns over the 12-month period beginning three months after the end of fiscal year $t-1$ and ending three months after the end of fiscal year $t$.
} 
$E A R N^{*} A N T I T A K E O V E R$ is positive and significant, indicating that earnings became more informative following the passage of antitakeover laws. ${ }^{20}$

To identify the source of this increased informativeness, we next examine whether managers used the discretion inherent in financial reporting to provide more private information through the use of accruals. Prior studies suggest that managers use their reporting discretion to signal their private information through accruals (e.g., Watts and Zimmerman, 1986; Guay et al., 1996). Specifically, in making discretionary accrual choices, which are inherently subjective, managers may incorporate their private information in the financial reports to credibly convey this information to financial statement users and improve the informativeness of reported accounting numbers (e.g., Watts and Zimmerman, 1986; Bernard and Skinner, 1996; Subramanyam, 1996).

In the second column, we decompose earnings into their cash flow and accrual components, and we interact each of these variables with ANTITAKEOVER. In the third and fourth columns, we further decompose total accruals into their discretionary and nondiscretionary components according to either the Jones (1991) model or the performancematched discretionary accruals model of Kothari et al. (2005), respectively. The Jones model

\footnotetext{
${ }^{20}$ Similar to the concern noted above about how changes in the probability of takeover might induce a mechanical change in the RSQ measure of financial statement informativeness, the dependent variable in this test is returns, which is a function of price and therefore might also be affected by a mechanical relation between the probability of takeover and the variability of prices. To address this concern, we calculate the ex ante probability of takeover for each firm-year (based on Cremers et al., 2009) and rank observations into terciles according to whether they have a low, medium, or high probability of takeover. We then interact the tercile rank of the probability of takeover with earnings (EARN), antitakeover (ANTITAKEOVER), and the earnings-antitakeover interaction $\left(E A R N^{*} A N T I T A K E O V E R\right)$. This is a more general specification that allows the relation between earnings and returns to differ according to differences in the probability of takeover both before and after the passage of the antitakeover laws. We find that none of the three additional interactions is significantly different from zero, which indicates that the mapping between earnings and returns was not different either before or after the passage of the antitakeover laws as a function of the probability of takeover. In addition, we continue to find that the coefficient on the EARN*ANTITAKEOVER interaction is positive and significant. Collectively, these results suggest that the earnings-returns relation strengthened following the passage of the antitakeover laws and that this change was not due to a mechanical relation between the probability of takeover and returns.
} 
uses the residuals from the following equation estimated annually for each industry based on the two-digit SIC:

$$
\frac{\text { TA }_{i t}}{\text { Assets }_{i, t-1}}=k_{1 t} \frac{1}{\text { Assets }_{i, t-1}}+k_{2} \frac{\Delta \operatorname{Rev}_{i t}}{\text { Assets }_{i, t-1}}+k_{3} \frac{P P E_{i t}}{\text { Assets }_{i, t-1}}+\varepsilon_{i t}
$$

where $T A$ is total accruals, which is calculated as the difference between net income (Compustat Data18) and cash flow from operations (Compustat Data308), Assets is total assets (Compustat Data6), $\triangle \mathrm{REV}$ is change in sales (Compustat Data12), $P P E$ is the net book value of property, plant, and equipment (Compustat Data8), and $i$ and $t$ index the firm and year, respectively.

Our second measure of discretionary accruals is the performance-adjusted abnormal accruals measure developed by Kothari et al. (2005). This measure also uses the residuals from the following equation, which is also estimated annually for each industry based on the two-digit SIC:

$$
\frac{\text { TA }_{i t}}{\text { Assets }_{i, t-1}}=k_{1 t} \frac{1}{\text { Assets }_{i, t-1}}+k_{2} \frac{\Delta \operatorname{Rev}_{i t}}{\text { Assets }_{i, t-1}}+k_{3} \frac{P P E_{i t}}{\text { Assets }_{i, t-1}}+k_{4} \text { ROA }_{i, t-1}+\varepsilon_{i t}
$$

where ROA is the return on assets computed as net income scaled by total assets, $i$ and $t$ index the firm and year, respectively, and the other variables are as previously defined.

The results in the second column of Table 10, where earnings are disaggregated into their cash flow and total accrual components, indicate that the increased informativeness of earnings following the passage of the antitakeover laws is attributable to the increased informativeness of accruals rather than cash flows. In particular, the coefficient on the interaction between total accruals and ANTITAKEOVER is positive and significant, but the interaction between cash flows and ANTITAKEOVER is statistically indistinguishable from zero. When we further disaggregate total accruals into their discretionary and nondiscretionary components according to the Jones model in the third column, we find that the increased informativeness of earnings following the 
passage of the antitakeover laws is attributable to the discretionary rather than the nondiscretionary component of accruals. When we use the performance-matched discretionary accruals model of Kothari et al. (2005), we find that both components of total accruals became more informative following the passage of the antitakeover laws. Overall, the evidence in Table 10 indicates that the accrual, rather than the cash flow component of earnings, is the source of the increased returns-earnings relation following the passage of the antitakeover laws. In addition, the evidence in Table 10 is consistent with managers' use of their discretion in financial reporting to convey more information to the capital markets following the passage of the antitakeover laws.

\subsubsection{Strength of antitakeover laws}

As discussed in Section 2.1, there is variation across states in the strength of their antitakeover laws, suggesting that their effect on firms' information environments might be expected to differ. There are two alternative approaches to classify the various state antitakeover laws as either "strong” or "weak." One classification is based on prior studies such as Francis et al. (2009) and Cheng et al. (2004), which considers a particular state antitakeover law to be strong if it contains more than two provisions and weak if it has only one or two provisions. Although this classification is objective, it ignores intricacies in the laws and their enforcement. $^{21}$ The second classification is based SharkRepellent.net, which provides a comprehensive database of the various state antitakeover statutes, including a detailed analysis of whether a particular state's antitakeover laws are strong or weak. We adopt both approaches for classifying the various state antitakeover laws.

\footnotetext{
${ }^{21}$ For example, Pennsylvania Senate Bill 1310 is widely regarded as the most stringent of the second-generation antitakeover laws and includes five provisions, including control shares, disgorgement, fiduciary duty, employee severance compensation, and labor contracts. Although this specific bill consists of five different provisions, it is accepted that it really includes only three major provisions, as the employee compensation and labor contract provisions are triggered by the share control approval provision.
} 
In an adapted version of Equation (1), we partition the ANTITAKEOVER indicator into STRONG_ANTITAKEOVER and WEAK_ANTITAKEOVER, which take values of one if the firmyear is from a state with either strong or weak antitakeover laws, respectively, in effect during the year and zero otherwise. The dependent variables are the measures of financial statement informativeness as well as the three measures of information asymmetry. In untabulated results, we find that, on average, the information environment of firms in states with stronger antitakeover laws improved more than the information environment of firms in states with weaker antitakeover laws.

\subsubsection{Delaware incorporation}

One concern with any study that examines the effect of state antitakeover laws is that a majority of U.S. publicly traded companies are incorporated in Delaware. It is therefore reasonable to ask whether the effect of the antitakeover laws is concentrated in firms incorporated in Delaware (in which case there is an identification problem that precludes identifying whether the effects are attributable to the antitakeover laws or being incorporated in Delaware) or whether the effects also occur in other states. To address this concern, we partition the ANTITAKEOVER indicator into DE_ANTITAKEOVER and OTHER_ANTITAKEOVER, which take values of one if the firm-year is from Delaware or another state with antitakeover laws, respectively, during a year in which antitakeover laws were in effect and zero otherwise. Untabulated results indicate that the effect of the antitakeover laws on the information asymmetry measures is not due solely to the firms incorporated in Delaware, but is also found in firms incorporated in other states that also passed antitakeover laws. 


\section{Conclusion}

We use changes in state antitakeover laws as source of exogenous variation in an important corporate governance mechanism (i.e., the market for corporate control) to examine the causal relation between firms' corporate governance structures and their information environments. Using a number of alternative proxies for firms' information environments, we find that the level of information asymmetry decreased, private information collection activities decreased, and the level of financial statement informativeness increased following the passage of the antitakeover laws. Consistent with the theories of Edlin and Stiglitz (1995) and Shleifer and Vishny (1989), our evidence suggests that information quality serves as a substitute for an important governance mechanism (i.e., monitoring from the market for corporate control).

Although we focus on the direct effect of antitakeover laws on firms' information environments, there are a number of potential indirect effects that might warrant future research. In particular, firms might have responded to the weakening of the market for corporate control by implementing alternative governance mechanisms with different informational requirements. For example, Williamson (1983) suggests that the market for corporate control and monitoring by the board of directors are substitute governance mechanisms. Therefore, if firms responded to the weakened capital market monitoring with greater internal monitoring in the form of either more or a higher proportion of outside directors, these directors would be likely to require higher-quality information to effectively discharge their monitoring duties (Armstrong et al., 2010). The increase in financial statement transparency and the decrease in the overall level of information asymmetry that we document are consistent with such a scenario. 


\section{References}

Ajinkya, B., Bhojraj, S., Sengupta, P., 2005. The association between outside directors, institutional investors, and the properties of management earnings forecasts. Journal of Accounting Research 43, 343-376.

Ambrose, B.W., Megginson, W.L., 1992. The role of asset structure, ownership structure, and takeover defenses in determining acquisition likelihood. Journal of Financial and Quantitative Analysis 27, 575-589.

Armstrong, C.S., Core, J.E., Taylor, D.J., Verrecchia, R.E., 2011. When does information asymmetry affect the cost of capital? Journal of Accounting Research 49, 1-40.

Armstrong, C.S., Guay, W.R., Weber, J.P., 2010. The role of information and financial reporting in corporate governance and contracting. Journal of Accounting and Economics 50, 179234.

Barth, M.E., Cram, D.P., Nelson, K.K., 2001. Accruals and the prediction of future cash flows. The Accounting Review 76, 27-58.

Bernard, V.L., Skinner, D.J., 1996. What motivates managers' choice of discretionary accruals? Journal of Accounting and Economics 22, 313-325.

Bertrand, M., Duflo, E., Mullainathan, S., 2004. How much should we trust differences-indifferences estimates? Quarterly Journal of Economics 119, 249-275.

Bertrand, M., Mullainathan, S., 1999. Is there discretion in wage setting? A test using takeover legislation. RAND Journal of Economics 30, 535-554.

Bertrand, M., Mullainathan, S., 2000. Agents with and without principals. American Economic Review 90, 203-208.

Bertrand, M., Mullainathan, S., 2003. Enjoying the quiet life? Corporate governance and managerial preferences. Journal of Political Economy 111, 1043-1075.

Beyer, A., Cohen, D., Lys, T., Walther, B., 2010. The financial reporting environment: review of the recent literature. Journal of Accounting and Economics 50, 296-343.

Brennan, M.J., Subrahmanyam, A., 1996. Market microstructure and asset pricing: on the compensation for illiquidity in stock returns. Journal of Financial Economics 41, 441-464.

Bushman, R., Chen, Q., Engel, E., Smith, A., 2004. Financial accounting information, organizational complexity, and corporate governance systems. Journal of Accounting and Economics 37, 167-201.

Bushman, R.M., Smith, A.J., 2001. Financial accounting information and corporate governance. Journal of Accounting and Economics 32, 237-333.

Bushman, R.M., Smith, A.J., 2003. Transparency, financial accounting information, and corporate governance. Economic Policy Review 9, 65-87.

Cai, J., Liu, Y., Qian, Y., 2009. Information asymmetry and corporate governance. Working paper.

Chen, L., Novy-Marx, R., Zhang, L., 2010. An Alternative Three-Factor Model. Working paper.

Cheng, S., Nagar, V., Rajan, M., 2004. Identifying control motives in managerial ownership: Evidence from antitakeover legislation. Review of Financial Studies 18, 637-672. 
Cheng, S., Indjejikian, R.J., 2009. The market for corporate control and CEO compensation: complements or substitutes? Contemporary Accounting Research 26, 701-728.

Comment, R., Schwert, W.G., 1995. Poison or placebo? Evidence on the deterrence and wealth effects of modern antitakeover measures. Journal of Financial Economics 39, 3-43.

Core, J.E., Guay, W.R., Larcker, D.F., 2003. Executive equity compensation and incentives: a survey. Economic Policy Review 9, 27-50.

Cremers, M., Nair, V., John, K., 2009. Takeover and cross-section of returns. Review of Financial Studies 22, 1409-1455.

Dechow, P., Ge, W., Schrand, C., 2010. Understanding earnings quality: a review of the proxies, their determinants, and their consequences. Working paper.

DeFond, M., Hann, R., Hu, X., 2005. Does the market value financial expertise on audit committees of boards of directors? Journal of Accounting Research 43, 153-193.

Easley, D., Hvidkjaer, S., O’Hara, M., 2002. Is information risk a determinant of asset returns? Journal of Finance 57, 2185-2221.

Easterbrook, F.H., Fischel, D.R., 1991. The economic structure of corporate law. Cambridge, Mass.: Harvard University Press.

Easton, P.D., Harris, T.S., 1991. Earnings as an explanatory variable for returns. Journal of Accounting Research 29, 19-36.

Edlin, A.S., Stiglitz, J.E., 1995. Discouraging rivals: managerial rent-seeking and economic inefficiencies. American Economic Review 85, 1301-1312.

Fama, E.F., French, K.R., 1993. Common risk factors in the returns on stocks and bonds. Journal of Financial Economics 33, 3-56.Fama, E. F., French, K.R., 1997. Industry costs of equity. Journal of Financial Economics 43, 153-193.

Fama, E.F., French, K.R., 2008. Dissecting anomalies. Journal of Finance 63, 1653-1678.

Ferreira, M.A., Laux, P.A., 2007. Corporate governance, idiosyncratic risk, and information flow. Journal of Finance 62, 951-989.

Francis, B., Hasan, I., John, K., Waisman, M., 2009. The effect of state antitakeover laws on the firm’s bondholders. Working paper.

Francis, J., Schipper, K., 1999. Have financial statements lost their relevance? Journal of Accounting Research 37, 319-352.

Francis, J., Schipper, K., Vincent, L., 2005. Earnings and dividend informativeness when cash flow rights are separated from voting rights. Journal of Accounting and Economics 39, 329360.

Frankel R., Li, X., 2004. Characteristics of a firm's information environment and the information asymmetry between insiders and outsiders. Journal of Accounting and Economics 37, 229259.

French, K.R., Roll, R., 1986. Stock return variances: the arrival of information and the reaction of traders. Journal of Financial Economics 17, 5-26.

Fu., H., Liu, M.H., 2008. Anti-takeover provisions and corporate disclosure. Working paper.

Garvey, G., Hanka, G., 1999. Capital structure and corporate control: The effect of antitakeover statutes on firm leverage. Journal of Finance 54, 519-546. 
Glosten, L.R., Milgrom, P.R., 1985. Bid, ask, and transaction prices in a specialist market with heterogeneously informed traders. Journal of Financial Economics 14, 71-100.

Gompers, P., Ishii, J., Metrick, A., 2008. Extreme governance: an analysis of dual-class companies in the United States. Review of Financial Studies 23, 1051-1088.

Guay, W.R., Kothari, S.P., Watts, R.L., 1996. A market-based evaluation of discretionary accrual models. Journal of Accounting Research 34, 83-105.

Jensen, M., 1993. The modern industrial revolution, exit, and the failure of internal control systems. Journal of Finance 48, 831-880.

Jones, J., 1991. Earnings management during import relief investigations. Journal of Accounting Research 29, 193-228.

Kothari, S.P., Leone, A.J., Wasley, C.E., 2005. Performance matched discretionary accruals. Journal of Accounting and Economics 39, 163-197.

Lang, M., Lundholm, R., 2000. Voluntary disclosure and equity offerings: Reducing information asymmetry or hyping the stock? Contemporary Accounting Research 17, 623-663.

LaFond, R., Watts, R.L., 2008. The information role of conservatism. The Accounting Review 83, 447-478.

Lakonishok, J., Lee, I., 2001. Are insider trades informative? Review of Financial Studies 14, 79-111.

Larcker, D.F., Lys, T., 1987. An analysis of the incentives to engage in costly information acquisition: the case of risk arbitrage. Journal of Financial Economics 18, 111-126.

Lee, C., Ready, M., 1991. Inferring trade direction from intraday data. Journal of Finance 46, 733-746.

Madhavan, A., Richardson, M., Roomans, M., 1997. Why do security prices change? A transaction-level analysis of NYSE stocks. Review of Financial Studies 10, 1035-1064.

Marquardt, C., Wiedman, C., 1998. Voluntary disclosure, information asymmetry, and insider selling through secondary equity offerings. Contemporary Accounting Research 15, 505537.

Mohanram, P., Rajgopal, S., 2009. Is PIN priced risk? Journal of Accounting and Economics 47, 226-243.

Petersen, M.A., 2009. Estimating standard errors in finance panel data sets: comparing approached. Review of Financial Studies 22, 435-480.

Roll, R., 1988. R². Journal of Finance 25, 541-566.

Romano, R., 1987. The political economy of takeover statutes. Virginia Law Review 73, 111199.

Rubin, D.B., 1974. Estimating causal effects of treatments in randomized and nonrandomized studies. Journal of Educational Psychology 66, 688-701.

Ruland, W., Tung, S., George, N.E., 1990. Factors associated with the disclosure of managers' forecasts. The Accounting Review 65, 710-721.

Schwert, G.W., 2000. Hostility in takeover: in the Eyes of the Beholder? Journal of Finance 55, 2599-2640. 
Shleifer, A., Vishny, R.W., 1989. Management entrenchment: the case of manager-specific investments. Journal of Financial Economics 25, 123-139.

Shleifer, A., Vishny, R.W., 1997. A survey of corporate governance. The Journal of Finance 52, 737-783.

Stein, J.C., 2003. Agency, information, and corporate investment. In: G. Constantinides, M. Harris, and R. Stulz, editors, Handbook of the Economics of Finance. North-Holland, Amsterdam.

Subramanyam, K.R., 1996. The pricing of discretionary accruals. Journal of Accounting and Economics 22, 249-281.

Warfield, T.D., Wild, J.J., Wild, K.K., 1995. Managerial ownership, accounting choices, and informativeness of earnings. Journal of Accounting and Economics 20, 61-91.

Watts, R., Zimmerman, J., 1986. Positive Accounting Theory. Prentice-Hall, Englewood Cliffs, N.J.

Williamson, O.E., 1983. Organization form, residual claimants, and corporate control. Journal of Law and Economics 26, 351-366.

Yu, F., 2008. Analyst coverage and earnings management. Journal of Financial Economics 88, 245-271. 


\section{Table 1}

\section{Antitakeover Laws by State}

Years of enactment of the antitakeover laws are obtained from Bertrand and Mullainathan (2003). Boldfaced states are those where the strength of the laws was high. The letters within parentheses denote the various statutes implemented in that state. Specifically, $a$ refers to Control Share Acquisition, $b$ refers to Freezeout Provision, $c$ refers to Fair Price Provision, $d$ refers to Anti-Greenmail Provision, $e$ refers to Golden Parachute Restrictions, $f$ refers to Expanded Constituency Provision, $g$ refers to Poison Pill Endorsement, $h$ refers to Assumption of Labor Contracts, $i$ refers to Disgorgement Provision, and $j$ refers to Control Share Cash-Out Statute.

\begin{tabular}{|c|c|c|c|c|c|}
\hline State & $\begin{array}{c}\text { Year of } \\
\text { enactment } \\
\text { of the law }\end{array}$ & $\begin{array}{c}\text { Number of } \\
\text { sample firms } \\
\text { incorporated } \\
\text { in the state }\end{array}$ & State & $\begin{array}{c}\text { Year of } \\
\text { enactment } \\
\text { of the law }\end{array}$ & $\begin{array}{c}\text { Number of } \\
\text { sample firms } \\
\text { incorporated } \\
\text { in the state }\end{array}$ \\
\hline Alabama & & 3 & Montana & & 1 \\
\hline Alaska & & 1 & Nebraska (a, b) & 1988 & 5 \\
\hline Arizona (a, b, c, d, e, f, g) & 1987 & 8 & Nevada (a, b, c, f, g) & 1991 & 101 \\
\hline Arkansas & & 4 & New Hampshire & & 0 \\
\hline California & & 206 & New Jersey (b, c, f, g) & 1986 & 76 \\
\hline Colorado & & 61 & New Mexico & & 2 \\
\hline Connecticut (b, c, f, g) & 1989 & 14 & New York (b, c, d, f, g) & 1985 & 138 \\
\hline Delaware (b, h) & 1988 & 2943 & North Carolina & & 36 \\
\hline District of Columbia & & 1 & North Dakota & & 0 \\
\hline Florida & & 131 & Ohio (a, b, c, f, g, i) & 1990 & 83 \\
\hline Georgia (b, c, g) & 1988 & 67 & Oklahoma (a, b) & 1991 & 18 \\
\hline Hawaii & & 2 & Oregon & & 47 \\
\hline Idaho (a, b, c, f, g) & 1988 & 2 & $\underset{i, j)}{\text { Pennsylvania (a, b, c, f, g, h, }}$ & 1989 & 111 \\
\hline Illinois (b, c, f, g, h) & 1989 & 21 & Rhode Island (b, c, f, g, h) & 1990 & 5 \\
\hline Indiana (a, b, c, f, g) & 1986 & 48 & South Carolina (a, b, g) & 1988 & 11 \\
\hline Iowa & & 8 & South Dakota (a, b, c, f, g, j) & 1990 & 4 \\
\hline Kansas (a, b) & 1989 & 9 & Tennessee (a, b, c, d, g) & 1988 & 37 \\
\hline Kentucky (b, c, f, g) & 1987 & 7 & Texas & & 89 \\
\hline Louisiana & & 11 & Utah & & 30 \\
\hline Maine (b, f, g, j) & 1988 & 4 & Vermont & & 3 \\
\hline Maryland (a, b, c, g) & 1989 & 48 & Virginia (a, b, c, g) & 1988 & 58 \\
\hline Massachusetts (a, b, c, g) & 1989 & 117 & Washington (b, c, g) & 1987 & 63 \\
\hline Michigan (a, b, c, g) & 1989 & 48 & West Virginia & & 1 \\
\hline Minnesota (a, b, c, d, e, f, g) & 1987 & 149 & Wisconsin (a, b, c, d, f, g) & 1987 & 50 \\
\hline Mississippi & & 2 & Wyoming (a, b, f) & 1989 & 2 \\
\hline Missouri (a, b, c, f, g) & 1986 & 30 & & & \\
\hline
\end{tabular}




\section{Table 2}

\section{Summary Statistics}

This table presents the summary statistics of the information environment variables used in this study. RSQ is the adjusted- $\mathrm{R}^{2}$ from a firm-specific time-series regression of price on earnings and book value of equity. PIN is the estimate of probability of information-based trading based on Easley et al. (2002). NPR is the net purchase transactions by management-insiders computed each firm-year as (number of purchase transactions less number of sales transactions) scaled by the (number of purchase transactions plus number of sales transactions) based on Frankel and Li (2004). LAMBDA is the adverse selection component of the bid-ask spread following Madhavan et al. (1997). SIGMA is the monthly logistic transformed relative idiosyncratic volatility estimated from the FamaFrench four-factor model (Ferreira and Laux 2007). AGE is the natural logarithm of the number of years a firm has a record in Compustat. SIZE is the natural logarithm of a firm's book value of assets (Compustat Data6).

\begin{tabular}{lcccccc}
\hline \multicolumn{1}{c}{ Variable } & $\mathrm{N}$ & Mean & Median & Std Dev & Minimum & Maximum \\
\hline & & & & & & \\
PIN & 24,052 & 0.209 & 0.199 & 0.074 & 0.062 & 0.488 \\
NPR & 23,549 & 0.313 & 1.000 & 0.836 & -1.000 & 1.000 \\
LAMBDA & 28,286 & 0.003 & 0.001 & 0.014 & 0.000 & 0.806 \\
SIGMA & 74,307 & 1.718 & 1.652 & 1.118 & -31.61 & 8.089 \\
RSQ & 25,064 & 0.354 & 0.306 & 0.259 & 0.002 & 0.970 \\
AGE & 28,286 & 2.534 & 2.565 & 0.815 & 0.693 & 3.871 \\
SIZE & 28,286 & 5.199 & 5.085 & 1.885 & 0.166 & 9.012 \\
& & & & & & \\
\hline
\end{tabular}




\section{Table 3}

\section{Antitakeover Laws and Information Asymmetry}

This table presents the results of the regression model that examines the effect of $\mathrm{BC}$ laws on analyst behavior. The dependent variable in Column (1) is PIN, in Column (2) is $L A M B D A$, in Column (3) is NPR, and in Column (4) is SIGMA. PIN, NPR and LAMBDA are defined in Table 2. ANTITAKEOVER is an indicator variable that equals one if the firm is incorporated in a state that has passed an antitakeover law. $A G E$ is the natural logarithm of the number of years a firm has a record in Compustat. SIZE is the natural logarithm of a firm's book value of assets (Compustat Data6). I_PIN, I_NPR, I_LAMBDA and I_SIGMA are variables that indicate the mean of PIN, NPR, LAMBDA, and SIGMA, respectively, in the firm's industry, excluding the firm itself. S_PIN, S_NPR, S_LAMBDA, and S_SIGMA are variables that indicate the mean of PIN, NPR, LAMBDA, and SIGMA, respectively, in the firm's state of location, excluding the firm itself. Standard errors are clustered at the state-of-incorporation level. The specifications include unreported annual and firm fixed-effects. $t$-statistics are presented beneath the coefficients within parentheses. *, **, and $* * *$ denote significance at $10 \%, 5 \%$, and $1 \%$, respectively.

\begin{tabular}{|c|c|c|c|c|}
\hline & $\begin{array}{l}(1) \\
P I N \\
\end{array}$ & $\begin{array}{c}(2) \\
L A M B D A \\
\end{array}$ & $\begin{array}{c}(3) \\
N P R\end{array}$ & $\begin{array}{c}(4) \\
\text { SIGMA }\end{array}$ \\
\hline ANTITAKEOVER & $\begin{array}{c}-0.008 * * \\
(-2.218)\end{array}$ & $\begin{array}{c}-0.001 * * * \\
(-3.895)\end{array}$ & $\begin{array}{c}-0.284 * * \\
(-2.469)\end{array}$ & $\begin{array}{c}-0.103^{* * *} \\
(-5.212)\end{array}$ \\
\hline$A G E$ & $\begin{array}{c}0.009 * * * \\
(3.039)\end{array}$ & $\begin{array}{c}0.001^{* *} \\
(2.570)\end{array}$ & $\begin{array}{c}0.079 * * * \\
(3.835)\end{array}$ & $\begin{array}{c}-0.046 * * * \\
(-2.923)\end{array}$ \\
\hline SIZE & $\begin{array}{c}-0.024^{* * *} \\
(-12.22)\end{array}$ & $\begin{array}{c}-0.001 * * * \\
(-4.625)\end{array}$ & $\begin{array}{c}-0.044^{* * *} \\
(-3.481)\end{array}$ & $\begin{array}{c}-0.100 * * * \\
(-16.24)\end{array}$ \\
\hline S_PIN & $\begin{array}{c}0.225^{* * *} \\
(8.446)\end{array}$ & & & \\
\hline$I \_P I N$ & $\begin{array}{c}0.100^{* * *} \\
(7.902)\end{array}$ & & & \\
\hline S_LAMBDA & & $\begin{array}{l}0.002^{* *} \\
(2.647)\end{array}$ & & \\
\hline I_LAMBDA & & $\begin{array}{c}0.000 \\
(0.454)\end{array}$ & & \\
\hline$S \_N P R$ & & & $\begin{array}{c}0.037 \\
(0.739)\end{array}$ & \\
\hline$I \_N P R$ & & & $\begin{array}{c}0.101^{* * *} \\
(3.914)\end{array}$ & \\
\hline S_SIGMA & & & & $\begin{array}{c}0.032 \\
(1.207)\end{array}$ \\
\hline I_SIGMA & & & & $\begin{array}{c}0.146^{* * *} \\
(12.18)\end{array}$ \\
\hline Observations & 24,052 & 28,286 & 23,549 & 74,086 \\
\hline R-squared & 0.638 & 0.228 & 0.424 & 0.259 \\
\hline Adj. R-squared & 0.584 & 0.0609 & 0.236 & 0.127 \\
\hline
\end{tabular}




\section{Table 4}

\section{Effect of Lobbying}

This table presents the results of the regression model that examines the role of lobbying in the relation between antitakeover laws and firms' information environment. ANTITAKEOVER (-1) is an indicator variable that equals one if the firm is incorporated in a state that will pass an antitakeover law in one year from now. ANTITAKEOVER (0) is an indicator variable that equals one if the firm is incorporated in a state that passes an antitakeover law this year. ANTITAKEOVER (1) and ANTITAKEOVER (2+) are dummy variables that equal one if the firm is incorporated in a state that passed a antitakeover law one year and two or more years ago, respectively. All other variables are defined in previous tables. Standard errors are clustered at the state-of-incorporation level. Time-effects and firm-effects are included. $t$-statistics are presented beneath the coefficients within parentheses. ${ }^{*}, * *$, and ${ }^{* * *}$ denote significance at $10 \%, 5 \%$, and $1 \%$, respectively.

\begin{tabular}{|c|c|c|c|c|}
\hline & $\begin{array}{l}(1) \\
P I N \\
\end{array}$ & $\begin{array}{c}(2) \\
L A M B D A\end{array}$ & $\begin{array}{c}\text { (3) } \\
N P R\end{array}$ & $\begin{array}{c}(4) \\
\text { SIGMA }\end{array}$ \\
\hline ANTITAKEOVER (-1) & $\begin{array}{c}-0.002 \\
(-0.435)\end{array}$ & $\begin{array}{c}0.001 \\
(0.887)\end{array}$ & $\begin{array}{c}-0.213 \\
(-1.133)\end{array}$ & $\begin{array}{c}0.008 \\
(0.375)\end{array}$ \\
\hline ANTITAKEOVER (0) & $\begin{array}{c}-0.004 * * \\
(-2.093)\end{array}$ & $\begin{array}{c}-0.001 * * * \\
(-4.396)\end{array}$ & $\begin{array}{c}-0.326 * * \\
(-2.561)\end{array}$ & $\begin{array}{c}-0.109 * * * \\
(-6.221)\end{array}$ \\
\hline ANTITAKEOVER (1) & $\begin{array}{c}-0.006 * * \\
(-2.251)\end{array}$ & $\begin{array}{c}-0.001 \\
(-1.244)\end{array}$ & $\begin{array}{c}-0.444 * * * \\
(-3.839)\end{array}$ & $\begin{array}{c}-0.095^{* * *} \\
(-3.601)\end{array}$ \\
\hline ANTITAKEOVER (2+) & $\begin{array}{c}-0.013 * * * \\
(-3.888)\end{array}$ & $\begin{array}{c}-0.001^{* *} \\
(-2.288)\end{array}$ & $\begin{array}{c}-0.518^{* * *} \\
(-3.969)\end{array}$ & $\begin{array}{c}-0.083^{* * *} \\
(-3.255)\end{array}$ \\
\hline$A G E$ & $\begin{array}{c}0.012^{* * *} \\
(3.861)\end{array}$ & $\begin{array}{c}0.001^{* *} \\
(2.348)\end{array}$ & $\begin{array}{c}0.160^{* * *} \\
(4.532)\end{array}$ & $\begin{array}{c}-0.054 * * * \\
(-2.715)\end{array}$ \\
\hline SIZE & $\begin{array}{c}-0.024^{* * *} \\
(-12.30)\end{array}$ & $\begin{array}{c}-0.001 * * * \\
(-4.532)\end{array}$ & $\begin{array}{c}-0.036 * * * \\
(-3.041)\end{array}$ & $\begin{array}{c}-0.100 * * * \\
(-16.39)\end{array}$ \\
\hline I_PIN & $\begin{array}{c}0.096 * * * \\
(7.559)\end{array}$ & & & \\
\hline S_PIN & $\begin{array}{c}0.199 * * * \\
(7.863)\end{array}$ & & & \\
\hline I_LAMBDA & & $\begin{array}{c}0.000 \\
(0.454)\end{array}$ & & \\
\hline S_LAMBDA & & $\begin{array}{l}0.002^{* *} \\
(2.661)\end{array}$ & & \\
\hline$I \_N P R$ & & & $\begin{array}{c}0.101^{* * *} \\
(3.815)\end{array}$ & \\
\hline$S \_N P R$ & & & $\begin{array}{c}0.041 \\
(0.836)\end{array}$ & \\
\hline I_SIGMA & & & & $\begin{array}{c}0.146^{* * *} \\
(12.22)\end{array}$ \\
\hline S_SIGMA & & & & $\begin{array}{c}0.037 \\
(1.356)\end{array}$ \\
\hline Observations & 24,052 & 28,286 & 23,549 & 74,086 \\
\hline R-squared & 0.639 & 0.228 & 0.425 & 0.259 \\
\hline Adj. R-squared & 0.584 & 0.061 & 0.237 & 0.127 \\
\hline
\end{tabular}




\section{Table 5}

\section{Antitakeover Laws and Financial Statement Informativeness}

This table presents the results of the regression model that examines the effect of antitakeover laws on accounting informativeness. The dependent variable in Columns (1) and (2) is $R S Q$, as defined in Table 2. I_RSQ and $S \_R S Q$ are the mean values of $R S Q$ in the firm's industry and state of location, respectively, excluding the firm itself. The dependent variable in Columns (3) and (4) is $E Q$, is the absolute value of residuals from the accruals model as defined in Barth et al. (2001). I_EQ and $S \_E Q$ are the mean values of $E Q$ in the firm's industry and state of location, respectively, excluding the firm itself. All other variables are as defined in the previous tables. Standard errors are clustered at the state-of-incorporation level. The specifications include unreported annual and firm fixed-effects. $t$ statistics are presented beneath the coefficients within parentheses. *, **, and *** denote significance at $10 \%, 5 \%$, and $1 \%$, respectively.

\begin{tabular}{|c|c|c|c|c|}
\hline & $\begin{array}{c}(1) \\
R S Q\end{array}$ & $\begin{array}{c}(2) \\
R S Q\end{array}$ & $\begin{array}{l}(3) \\
E Q\end{array}$ & $\begin{array}{l}\text { (4) } \\
E Q\end{array}$ \\
\hline ANTITAKEOVER & $\begin{array}{l}0.017^{* *} \\
(2.470)\end{array}$ & & $\begin{array}{c}-0.008 * * * \\
(-5.370)\end{array}$ & \\
\hline ANTITAKEOVER (-1) & & $\begin{array}{c}0.000 \\
(0.0318)\end{array}$ & & $\begin{array}{c}-0.003 \\
(-1.219)\end{array}$ \\
\hline ANTITAKEOVER (0) & & $\begin{array}{c}-0.004 \\
(-0.373)\end{array}$ & & $\begin{array}{c}-0.010^{* * *} \\
(-5.206)\end{array}$ \\
\hline ANTITAKEOVER (1) & & $\begin{array}{c}0.007 \\
(0.511)\end{array}$ & & $\begin{array}{c}-0.009 * * * \\
(-5.752)\end{array}$ \\
\hline ANTITAKEOVER (2+) & & $\begin{array}{l}0.031^{* *} \\
(2.126)\end{array}$ & & $\begin{array}{c}-0.011 * * * * \\
(-6.897)\end{array}$ \\
\hline$I \_R S Q$ & $\begin{array}{c}0.059 * * * \\
(2.931)\end{array}$ & $\begin{array}{c}0.057 * * * \\
(3.004)\end{array}$ & & \\
\hline$S \_R S Q$ & $\begin{array}{c}-0.027 \\
(-0.363)\end{array}$ & $\begin{array}{c}-0.056 \\
(-0.856)\end{array}$ & & \\
\hline I_EQ & & & $\begin{array}{c}0.051^{* * *} \\
(3.220)\end{array}$ & $\begin{array}{c}0.051^{* * *} \\
(3.226)\end{array}$ \\
\hline$S \_E Q$ & & & $\begin{array}{c}-0.042 \\
(-1.567)\end{array}$ & $\begin{array}{c}-0.045 \\
(-1.664)\end{array}$ \\
\hline SIZE & $\begin{array}{c}-0.011 \\
(-1.586)\end{array}$ & $\begin{array}{c}-0.011 \\
(-1.545)\end{array}$ & $\begin{array}{c}-0.006 * * * \\
(-12.64)\end{array}$ & $\begin{array}{c}-0.006 * * * \\
(-12.26)\end{array}$ \\
\hline$A G E$ & $\begin{array}{c}-0.123^{* * *} \\
(-4.981)\end{array}$ & $\begin{array}{c}-0.144 * * * \\
(-4.291)\end{array}$ & $\begin{array}{c}0.001 \\
(0.829)\end{array}$ & $\begin{array}{c}0.001 \\
(1.119)\end{array}$ \\
\hline Observations & 27,622 & 27,622 & 36,814 & 36,814 \\
\hline R-squared & 0.530 & 0.530 & 0.355 & 0.355 \\
\hline Adj. R-squared & 0.461 & 0.462 & 0.217 & 0.217 \\
\hline
\end{tabular}




\section{Table 6}

\section{Antitakeover Laws and Analyst Behavior}

This table presents the results of the regression model that examines the effect of antitakeover laws on analyst behavior. The dependent variable in Column (1) is COVERAGE, in Column (2) is DISPERSION, and Column (3) is AF_ERROR. COVERAGE is the number of estimates in the annual earnings forecast. DISPERSION is the standard deviation of the annual earnings forecast scaled by the mean estimate. AF_ERROR is the absolute analyst forecast error computed as the actual estimate less the mean estimate scaled by logarithm of firm assets. ANTITAKEOVER is an indicator variable that equals one if the firm is incorporated in a state that has passed an antitakeover law. AGE is the natural logarithm of the number of years a firm has a record in Compustat. SIZE is the natural logarithm of a firm's book value of assets (Compustat Data6). I_COVERAGE, I_DISPERSION, and I_AF_ERROR are variables that indicate the mean of COVERAGE, DISPERSION, and AF_ERROR, respectively, in the firm's industry, excluding the firm itself. S_COVERAGE, S_DISPERSION, and $S_{-} A F_{-} E R R O R$ are variables that indicate the mean of COVERAGE, DISPERSION, and AF_ERROR, respectively, in the firm's state of location, excluding the firm itself. Standard errors are clustered at the state-of-incorporation level. The specifications include unreported annual fixed-effects.

\begin{tabular}{|c|c|c|c|}
\hline & $\begin{array}{c}(1) \\
\text { COVERAGE }\end{array}$ & $\begin{array}{c}(2) \\
\text { DISPERSION }\end{array}$ & $\begin{array}{c}(3) \\
A F \_E R R O R\end{array}$ \\
\hline ANTITAKEOVER & $\begin{array}{l}-0.428 * * \\
(-2.367)\end{array}$ & $\begin{array}{l}-0.021^{*} \\
(-1.944)\end{array}$ & $\begin{array}{l}-0.011^{* *} \\
(-1.976)\end{array}$ \\
\hline$A G E$ & $\begin{array}{l}-0.253^{*} \\
(-1.714)\end{array}$ & $\begin{array}{c}-0.021 * * * \\
(-3.114)\end{array}$ & $\begin{array}{c}0.038^{* * * *} \\
(16.99)\end{array}$ \\
\hline SIZE & $\begin{array}{c}2.115^{* * * *} \\
(30.28)\end{array}$ & $\begin{array}{c}0.014 * * * \\
(4.061)\end{array}$ & $\begin{array}{c}-0.023^{* * *} \\
(-17.12)\end{array}$ \\
\hline S_COVERAGE & $\begin{array}{c}0.490 * * * \\
(6.754)\end{array}$ & & \\
\hline I_COVERAGE & $\begin{array}{c}0.315^{* * *} \\
(12.35)\end{array}$ & & \\
\hline S_DISPERSION & & $\begin{array}{c}0.027 \\
(1.477)\end{array}$ & \\
\hline I_DISPERSION & & $\begin{array}{c}0.007 \\
(0.404)\end{array}$ & \\
\hline$S \_A F \_E R R O R$ & & & $\begin{array}{c}0.000 \\
(1.568)\end{array}$ \\
\hline$I \_A F \_E R R O R$ & & & $\begin{array}{l}-0.000 * \\
(-1.807)\end{array}$ \\
\hline Observations & 38,905 & 29,680 & 38,675 \\
\hline R-squared & 0.885 & 0.269 & 0.597 \\
\hline Adj. R-squared & 0.860 & 0.090 & 0.510 \\
\hline
\end{tabular}




\section{Table 7}

\section{Effect of Antitakeover Laws on Financial Statement Informativeness: The Role of the Quiet Life}

This table presents the results of the regression model that examines the effect of antitakeover laws on accounting informativeness for a subsample of firms where managers pursue the quiet life and those where managers do not. The dependent variable, $E Q$, is the absolute value of residuals from the accruals model as defined in Barth et al. (2001). I_EQ and S_EQ are the mean values of $E Q$ in the firm's industry and state of location, respectively, excluding the firm itself. All other variables are as defined in the previous tables. Columns (1), (3), (5), and (7) represent the subsample corresponding to the quiet life, and Columns (2), (4), (6), and (8) represent the subsample corresponding to firms that do not enjoy the quiet life. Standard errors are clustered at the state-of-incorporation level. The specifications include unreported annual and firm fixed-effects. $t$-statistics are presented beneath the coefficients within parentheses. ${ }^{* * *}$, and ${ }^{* * *}$ denote significance at $10 \%, 5 \%$, and $1 \%$, respectively.

\begin{tabular}{|c|c|c|c|c|c|c|c|c|}
\hline & $\begin{array}{l}(1) \\
E Q\end{array}$ & $\begin{array}{l}(2) \\
E Q\end{array}$ & $\begin{array}{l}(3) \\
E Q\end{array}$ & $\begin{array}{l}(4) \\
E Q\end{array}$ & $\begin{array}{l}(5) \\
E Q\end{array}$ & $\begin{array}{l}(6) \\
E Q\end{array}$ & $\begin{array}{l}(7) \\
E Q\end{array}$ & $\begin{array}{l}(8) \\
E Q\end{array}$ \\
\hline ANTITAKEOVER & $\begin{array}{c}-0.008 * * * \\
(-3.056)\end{array}$ & $\begin{array}{c}-0.007 * * * \\
(-2.879)\end{array}$ & $\begin{array}{c}-0.008^{* * *} \\
(-3.759)\end{array}$ & $\begin{array}{c}-0.009 * * * \\
(-4.056)\end{array}$ & $\begin{array}{c}-0.006 * * \\
(-2.753)\end{array}$ & $\begin{array}{c}-0.011 * * * \\
(-3.454)\end{array}$ & $\begin{array}{c}-0.013^{* * *} \\
(-4.494)\end{array}$ & $\begin{array}{c}-0.007 * * * \\
(-4.333)\end{array}$ \\
\hline$I \_E Q$ & $\begin{array}{l}0.087^{*} \\
(1.996)\end{array}$ & $\begin{array}{l}-0.055^{*} \\
(-1.836)\end{array}$ & $\begin{array}{c}-0.104^{*} \\
(-1.765)\end{array}$ & $\begin{array}{c}-0.024 \\
(-0.873)\end{array}$ & $\begin{array}{l}-0.084^{*} \\
(-1.814)\end{array}$ & $\begin{array}{c}-0.027 \\
(-0.948)\end{array}$ & $\begin{array}{c}-0.100 \\
(-1.042)\end{array}$ & $\begin{array}{c}-0.036 \\
(-1.376)\end{array}$ \\
\hline$S \_E Q$ & $\begin{array}{c}0.099 * * * \\
(3.122)\end{array}$ & $\begin{array}{l}0.042^{* *} \\
(2.609)\end{array}$ & $\begin{array}{l}0.079 * \\
(1.950)\end{array}$ & $\begin{array}{c}0.042^{* * *} \\
(2.784)\end{array}$ & $\begin{array}{c}0.080^{* * * *} \\
(3.763)\end{array}$ & $\begin{array}{c}0.032 \\
(1.564)\end{array}$ & $\begin{array}{c}0.069 \\
(1.518)\end{array}$ & $\begin{array}{c}0.047^{* * *} \\
(3.196)\end{array}$ \\
\hline SIZE & $\begin{array}{c}0.007^{* * *} \\
(2.811)\end{array}$ & $\begin{array}{c}0.001 \\
(0.910)\end{array}$ & $\begin{array}{c}0.002 \\
(0.556)\end{array}$ & $\begin{array}{c}0.001 \\
(0.617)\end{array}$ & $\begin{array}{c}0.002 \\
(1.080)\end{array}$ & $\begin{array}{c}0.001 \\
(0.697)\end{array}$ & $\begin{array}{c}0.008 \\
(1.701)\end{array}$ & $\begin{array}{c}0.000 \\
(0.0150)\end{array}$ \\
\hline$A G E$ & $\begin{array}{c}-0.005^{* * *} \\
(-3.010)\end{array}$ & $\begin{array}{c}-0.006 * * * \\
(-12.76)\end{array}$ & $\begin{array}{c}-0.005^{* * *} \\
(-3.508)\end{array}$ & $\begin{array}{c}-0.007 * * * \\
(-10.88)\end{array}$ & $\begin{array}{c}-0.005^{* * *} \\
(-6.391)\end{array}$ & $\begin{array}{c}-0.007 * * * \\
(-10.97)\end{array}$ & $\begin{array}{c}-0.005^{* * *} \\
(-3.393)\end{array}$ & $\begin{array}{c}-0.007 * * * \\
(-12.26)\end{array}$ \\
\hline Sample & $\begin{array}{l}\text { Negative } \\
\text { Asset } \\
\text { Growth }\end{array}$ & $\begin{array}{l}\text { Positive } \\
\text { Asset } \\
\text { Growth }\end{array}$ & $\begin{array}{l}\text { Negative } \\
\text { PP\&E } \\
\text { Growth }\end{array}$ & $\begin{array}{l}\text { Positive } \\
\text { PP\&E } \\
\text { Growth }\end{array}$ & $\begin{array}{l}\text { Negative } \\
\text { COGS } \\
\text { Growth }\end{array}$ & $\begin{array}{l}\text { Positive } \\
\text { COGS } \\
\text { Growth }\end{array}$ & $\begin{array}{c}\text { Negative } \\
\text { Adv Exp } \\
\text { Growth }\end{array}$ & $\begin{array}{l}\text { Positive } \\
\text { Adv Exp } \\
\text { Growth }\end{array}$ \\
\hline Observations & 6,774 & 30,040 & 6,083 & 30,731 & 13,390 & 23,424 & 4,942 & 31,872 \\
\hline R-squared & 0.300 & 0.365 & 0.320 & 0.360 & 0.303 & 0.376 & 0.313 & 0.361 \\
\hline Adj. R-squared & 0.193 & 0.219 & 0.217 & 0.214 & 0.204 & 0.213 & 0.217 & 0.215 \\
\hline
\end{tabular}




\section{Table 8 \\ Effect of Antitakeover Laws on Financial Statement Informativeness: The Role of Career Concerns}

This table presents the results of the regression model that examines the effect of antitakeover laws on accounting informativeness for the subsample of firms with low and high (i.e., below and above the median value, respectively) probability of takeover, which is estimated as the predicted value from the logistic regression specified in Cremers, Nair, and John (2009) and described in Section 4.4. I_EQ and S_EQ are the mean values of EQ in the firm's industry and state of location, respectively, excluding the firm itself. $I \_R S Q$ and $S \_R S Q$ are the mean values of $R S Q$ in the firm's industry and state of location, respectively, excluding the firm itself. All other variables are as defined in the previous tables. Standard errors are clustered at the state-of-incorporation level. The specifications include unreported annual and firm fixed-effects. $t$-statistics are presented beneath the coefficients within parentheses. *, **, and $* * *$ denote significance at $10 \%, 5 \%$, and $1 \%$, respectively.

\begin{tabular}{lcc}
\hline & $(1)$ & $(2)$ \\
& $E Q$ & $E Q$ \\
\hline \multirow{2}{*}{ ANTITAKEOVER } & $-0.014^{* *}$ & $-0.004^{* *}$ \\
& $(-2.227)$ & $(-2.398)$ \\
S_EQ & 0.028 & $0.049^{* *}$ \\
& $(0.839)$ & $(2.140)$ \\
SIZE & 0.018 & -0.003 \\
& $(0.311)$ & $(-0.073)$ \\
AGE & $-0.007^{* * *}$ & $-0.005^{* * *}$ \\
& $(-4.846)$ & $(-7.449)$ \\
& $0.007 * * *$ & $0.005^{* * *}$ \\
Sample & $(-2.561)$ & $(5.564)$ \\
& & \\
Observations & Below Median & Above Median \\
R-squared & Probability of & Probability of \\
Adj. R-squared & Takeover & Takeover \\
\hline
\end{tabular}




\section{Table 9}

\section{Effect of Antitakeover Laws on Financial Statement Informativeness: The Role of Equity Issuance}

This table presents the results of the regression model that examines the effect of antitakeover laws on accounting informativeness for the subsample of firms with and without equity issuance. The dependent variable, $E Q$, is the absolute value of residuals from the accruals model as defined in Barth et al. (2001). I_EQ and S_EQ are the mean values of $E Q$ in the firm's industry and state of location, respectively, excluding the firm itself. All other variables are as defined in the previous tables. Equity issuance is defined based on Chen et al. (2010) as the ratio of splitadjusted shares outstanding between two years. Standard errors are clustered at the state-of-incorporation level. The specifications include unreported annual and firm fixed-effects. $t$-statistics are presented beneath the coefficients within parentheses. *, **, and $* * *$ denote significance at $10 \%, 5 \%$, and $1 \%$, respectively.

\begin{tabular}{lcc}
\hline & $(1)$ & $(2)$ \\
& $E Q$ & $E Q$ \\
ANTITAKEOVER & $-0.006^{* *}$ & -0.005 \\
& $(-2.495)$ & $(-0.788)$ \\
$I \_E Q$ & -0.066 & 0.064 \\
& $(-1.142)$ & $(0.798)$ \\
S_EQ & $0.084^{* * *}$ & -0.046 \\
& $(3.614)$ & $(-1.098)$ \\
SIZE & 0.000 & 0.003 \\
& $(0.016)$ & $(1.151)$ \\
AGE & $-0.007^{* * *}$ & $-0.005^{* * *}$ \\
& $(-10.370)$ & $(-2.726)$ \\
Sample & & \\
& Net Equity Issuers & Non-Net Equity Issuers \\
Observations & & \\
R-squared & 25,895 & 8,886 \\
Adj. R-squared & 0.405 & 0.523 \\
\hline
\end{tabular}




\section{Table 10}

\section{Antitakeover Laws and Financial Reporting: An Alternative Approach}

This table presents the results of the regression model that examines the effect of antitakeover laws on the informativeness of accruals and cash flow based on the approach of Easton and Harris (1991). The dependent variable is cumulative return starting three months after fiscal year end $t-1$ to six months after fiscal year end $t$. $E A R N$ is the firm's earnings in year $t$ scaled by its assets at the end of year $t-1$. CFO is the firm's cash flow from operations in year $t$ scaled by its assets at the end of year $t-1$. TOT_ACCRUALS is a firm's earnings in year $t$ minus the cash flow from operations in year $t$ scaled by market value of equity at the end of year $t-1$. Columns (3) and (4) examine the informativeness of discretionary accruals (DA) and nondiscretionary accruals (ND_ACCRUALS). Column (3) uses the Jones model approach to calculate the discretionary accruals, while model (4) is performancematched discretionary accruals based on Kothari et al. (2005). ANTITAKEOVER is an indicator variable that equals one if the firm is incorporated in a state that has passed an antitakeover law. Standard errors are clustered at the state-of-incorporation level. Annual and firm fixed-effects are included but not reported. $t$-statistics are presented beneath the coefficients within parentheses. *, **, and *** denote significance at $10 \%, 5 \%$, and $1 \%$, respectively.

\begin{tabular}{|c|c|c|c|c|}
\hline & $\begin{array}{c}(1) \\
R E T\end{array}$ & $\begin{array}{c}(2) \\
R E T\end{array}$ & $\begin{array}{c}(3) \\
R E T\end{array}$ & $\begin{array}{c}(4) \\
R E T\end{array}$ \\
\hline$E A R N$ & $\begin{array}{c}0.868^{* * *} \\
(8.324)\end{array}$ & & & \\
\hline EARN * ANTITAKEOVER & $\begin{array}{c}0.506^{* * *} \\
(5.442)\end{array}$ & & & \\
\hline CFO & & $\begin{array}{c}0.741^{* * *} \\
(4.602)\end{array}$ & $\begin{array}{c}0.735^{* * *} \\
(4.442)\end{array}$ & $\begin{array}{c}0.736^{* * * *} \\
(4.621)\end{array}$ \\
\hline CFO * ANTITAKEOVER & & $\begin{array}{c}0.255 \\
(1.267)\end{array}$ & $\begin{array}{c}0.274 \\
(1.344)\end{array}$ & $\begin{array}{c}0.247 \\
(1.235)\end{array}$ \\
\hline TOT_ACCRUALS & & $\begin{array}{c}0.472 * * * \\
(3.971)\end{array}$ & & \\
\hline TOT_ACCRUALS*ANTITAKEOVER & & $\begin{array}{c}0.505^{* * *} \\
(3.622)\end{array}$ & & \\
\hline ND_ACCRUALS & & & $\begin{array}{c}0.568 * * * \\
(5.198)\end{array}$ & $\begin{array}{c}0.738^{* * *} \\
(2.963)\end{array}$ \\
\hline ND_ACCRUALS* ANTITAKEOVER & & & $\begin{array}{c}0.219 \\
(1.320)\end{array}$ & $\begin{array}{r}0.634^{* *} \\
(2.475)\end{array}$ \\
\hline$D A$ & & & $\begin{array}{c}0.447 * * * \\
(3.195)\end{array}$ & $\begin{array}{c}0.437 * * * \\
(3.916)\end{array}$ \\
\hline DA * ANTITAKEOVER & & & $\begin{array}{c}0.572 * * * \\
(3.686)\end{array}$ & $\begin{array}{c}0.482^{* * *} \\
(3.506)\end{array}$ \\
\hline ANTITAKEOVER & $\begin{array}{c}0.009 \\
(0.398)\end{array}$ & $\begin{array}{c}0.030 \\
(1.550)\end{array}$ & $\begin{array}{c}0.016 \\
(0.716)\end{array}$ & $\begin{array}{c}0.035 \\
(1.555)\end{array}$ \\
\hline Observations & 41,186 & 41,186 & 41,186 & 41,186 \\
\hline R-squared & 0.250 & 0.244 & 0.244 & 0.244 \\
\hline Adj. R-squared & 0.104 & 0.096 & 0.096 & 0.096 \\
\hline
\end{tabular}

